\title{
Sedimentary features observed in the tsunami deposits at Rikuzentakata City
}

\section{$\operatorname{AUTHOR}(\mathrm{S}):$}

Naruse, Hajime; Arai, Kazuno; Matsumoto, Dan; Takahashi, Hiroki; Yamashita, Shota; Tanaka, Gengo; Murayama, Masafumi

\section{CITATION:}

Naruse, Hajime ... [et al]. Sedimentary features observed in the tsunami deposits at Rikuzentakata City. Sedimentary Geology 2012, 282: 199-215

\section{ISSUE DATE:}

2012-12

URL:

http://hdl.handle.net/2433/166602

\section{RIGHT:}

(c) 2012 Elsevier B.V.; この論文は出版社版でありません。引用の際には 出版社版をご確認ご利用ください。; This is not the published version. Please cite only the published version. 
1 Sedimentary features observed in the tsunami deposits at Rikuzentakata City

Hajime Naruse $^{1 *}$, Kazuno Arai $^{2}$, Dan Matsumoto $^{3}$, Hiroki Takahashi ${ }^{2}$, Shota Yamashita $^{2}$, Gengo Tanaka ${ }^{4}$, and Masafumi Murayama ${ }^{5}$

${ }^{1}$ Kyoto University, Division of Earth and Planetary Sciences, Graduate School of Science, Kitashirakawa-Oiwakecho, Sakyo-ku, Kyoto 606-8502, Japan

${ }^{2}$ Chiba University, Division of Earth Sciences, Graduate School of Science, 1-33 Yayoicho, Inage-ku, Chiba 263-8522, Japan

${ }^{3}$ Advanced Industrial Science and Technology, Institute of Geology and Geoinformation, 1-1-1 Higashi, Tsukuba, Ibaraki 305-8561, Japan

${ }^{4}$ Gunma Museum of Natural History, 1674-1, Kamikuroiwa, Tomioka-shi, Gunma 370-2345, Japan

${ }^{5}$ Kochi University, Center for Advanced Marine Core Research, B200 Monobe, Nankoku, Kochi 783-8502, Japan

"Corresponding author: naruse@ kueps.kyoto-u.ac.jp Fax: +81-75-753-4189 


\section{Abstract}

The March 11, 2011 Tohoku-Oki tsunami triggered by an earthquake off the

5 east coast of northeastern Honshu Island (Tohoku region), Japan, deposited large

6 amounts of sediment on land, including the Sendai Plain and Sanriku Coast. This study

7 reports on the characteristics of the tsunami deposits in Rikuzentakata City, southeastern

8 Iwate Prefecture, northeastern Japan. A field survey identified the inundation pattern of

9 the tsunami in this region and the facies model of the tsunami deposits at the bay-head

10 deltas of estuarine systems. The tsunami deposits in Rikuzentakata City generally

11 consist of one to four units that represent a discrete runup or backwash flow. Each unit

12 is characterized by initial inverse grading and successive normal grading that

13 correspond to the accelerating and decelerating stages of the flow, respectively. An

14 internal erosional surface often developed between the inverse-graded and

15 normal-graded units. It corresponds to the maximum shear velocity of the flow and

16 truncates the underlying inverse-graded unit. In the case of the runup unit, silty

17 fine-grained drapes overlay the graded sandy interval. A correlation of the sedimentary

18 structures and grain fabric analysis revealed that the Tohoku-Oki tsunami inundated

19 Rikuzentakata City at least twice and that the flow velocity exceeded $2.4 \mathrm{~m} / \mathrm{s}$.

20 Paleontological analysis of the sediment and kriging estimation of the total volume of

21 the tsunami deposit implied that the sediments were sourced not only from eroded beach

22 sands but also from the seafloor of Hirota Bay or more offshore regions. 
23 KEYWORDS: tsunami; inverse-graded bedding; graded bedding; Northwest Pacific;

24 ostracods 


\section{1. Introduction}

The Tohoku-Oki tsunami was triggered by an earthquake that occurred at 14:46

on March 11, 2011, with the epicenter located off the east coast of northeastern Honshu

Island (Tohoku region), Japan (Fig. 1). The Mw 9.0 earthquake is the largest recorded

30 event in Japan (Fujii et al., 2011) and the fourth-largest in the last 100 years in the

31 World (Nettles et al., 2011). According to the Japan Meteorological Agency, the earthquake resulted from a series of seismogenic faulting events that began at $38.1035^{\circ} \mathrm{N}, 142.861^{\circ} \mathrm{E}, \mathrm{Mw} 9.0$ at $14: 46: 18 \mathrm{JST}$, along the Japan Trench, where the Pacific Plate is subducting beneath the North American Plate. The resulting tsunami spread across the North Pacific Ocean (Stimpson, 2011), striking coastal areas of Japan with a maximum run-up height of $39.7 \mathrm{~m}$ in Miyako city, Japan (Mori et al., 2011). As of 8 August, 2012 (National Policy Agency of Japan, 2012), the estimated fatalities were 15,868 with 2,848 persons still missing.

The tsunami inundation caused severe damage, especially in the coastal regions

40 of northeastern Japan, such as Fukushima, Miyagi, and Iwate Prefectures. This study

41 reports on the characteristic features of the tsunami deposits in Rikuzentakata City, southeastern Iwate Prefecture, northeastern Japan (Figs. 1 and 2). The city suffered catastrophic destruction (Figs. 3 and 4) with an estimated 1,552 fatalities and an additional 399 persons missing as of July $14, \quad 2011$ (http://sv032.office.pref.iwate.jp/ bousai/). This is the largest number of fatalities in Iwate Prefecture. The city remains at risk from future tsunamis, as do other areas with

47 similar topographic features, thus it is important to understand the behavior of tsunami 
waves in this region for future disaster mitigation. Another significance of the research in this region is that a field survey in Rikuzentakata City may potentially reveal features of tsunami deposition in natural environments without the influence of artificial

51 infrastructure. Most cities on the Sanriku Coast were protected by artificial coastal 52 levees, aiming at trapping most of the sediment transported by tsunami waves. Hence, 53 less deposition is expected than in the case of ancient tsunami deposits. In the case of 54 Rikuzentakata City, however, the first tsunami wave completely destroyed a 5.5-m-high coastal levee, resulting in large-scale erosion of the sandy coast (Fig. 3). This coastal erosion provided abundant source sediments that were deposited on land, forming a thick and extensive tsunami deposit. Therefore, it is expected that the facies model of the tsunami deposits in this region may be comparable to ancient events and will be helpful in deciphering geological records. There are also extensive studies of the 2011 Tohoku-Oki tsunami deposits on the Sendai Plain (e.g. Goto et al., 2011; submitted this issue; Abe et al., in press this issue), and therefore the future comparison of results between the Sanriku Coast and Sendai Plain regions will be significant, focusing on influences of topographic settings on the sedimentary features of tsunami deposits. This study aims to contribute to future research on tsunami deposits and disaster prevention from two viewpoints: (1) providing information about the behavior of the Tohoku-Oki tsunami in this region and (2) establishing a facies model of the tsunami deposits at the bay-head deltas of estuarine systems. Terrestrial tsunami deposits provide important information on the magnitude and recurrence intervals of tsunami events (Nanayama et al., 2003). Reconstruction of the hydraulic properties and magnitude of historical tsunamis from stratigraphic sequences can be useful in risk assessment studies. However, sandy beds in coastal stratigraphic successions may also 
72 be produced by events such as large-scale storms and river flooding (e.g., Switzer \&

73 Jones, 2008). Therefore, it is important to investigate the detailed features of recent

74 tsunami deposits from known source events because their sedimentological

75 characterization and relationship with the actual events are necessary for establishing

76 the criteria to identify tsunami deposits in the geological record.

Documentation of the Tohoku-Oki tsunami is also significant for the

verification and improvement of numerical tsunami models, which will be important for

future disaster-prevention measures. Direct measurements of flow velocities or

hydrographs of the tsunami are not available for this region; hence, an investigation of the deposits is useful in providing information on this hazard. From this viewpoint, the study examined the number of inundations, estimated minimum flow velocities, and calculated the total flux of tsunami sediment. These characteristics will be reproduced in

84 future studies by numerical models with sediment transport functions.

\section{$85 \quad 2 . \quad$ Study Region}

86 Rikuzentakata City, on the southern Sanriku Coast, is approximately $130 \mathrm{~km}$

87 west of the earthquake epicenter (Fig. 1). The central-southern part of the Sanriku Coast is a mountainous region with a deeply indented Ria coastline, which features a series of alternating capes and estuaries, with small bay-head deltas often developed at the river mouths.

Rikuzentakata City is located in an estuarine bay-head delta plain in the inner

92 part of Hirota Bay (Fig. 1 and 2). The coastal delta plain is approximately $2 \mathrm{~km}$ wide in

93 the north-south direction and extends for $2.5 \mathrm{~km}$ east-west. Most regions of the 
94 delta-plain are relatively flat and are less than $5 \mathrm{~m}$ above mean sea level. This delta

95 plain was formed by the $50 \mathrm{~km}$ long Kesen River, which has a drainage basin area of $96540 \mathrm{~km}^{2}$. Progradation of the delta was initiated approximately 6000 years before 97 present in response to Holocene sea level rise, and the modern delta plain was mostly 98 established by about 3000 years before present (Chida et al., 1984). The most prominent 99 topographic feature of Rikuzentakata City was the Takata-Matsubara pine forest, located 100 on a wave-dominated spit (Fig. 3) on top of which a 5.5-m-high coastal levee had been 101 built (Asano et al., 2009).

102 The maximum tsunami run-up height was $19.9 \mathrm{~m}$ in this region, and the inundation height (tsunami height above mean sea level) was approximately 14-15 m (reported by The 2011 Tohoku Earthquake Tsunami Joint Survey Group at http://www.coastal.jp/ttjt/). The exact number of inundations and periodicity of the tsunami waves at Rikuzentakata City is unknown because all tidal gauges and global

107 positioning system (GPS) buoys in this area were destroyed by the event. However, data 108 from a GPS buoy located off southern Iwate Prefecture $\left(39.3361^{\circ} \mathrm{N}, 141.9944^{\circ} \mathrm{E}\right)$, ca. 15

$109 \mathrm{~km}$ offshore, indicate that seven successive waves struck this coast (Takahashi et al., 110 2011). The first wave was the largest (6.7 $\mathrm{m}$ in height at this site), the second and fourth 111 waves were relatively high (approximately $2 \mathrm{~m}$ in height), and others were relatively 112 small (less than $1.5 \mathrm{~m}$ in height). The wave periodicity was approximately $50 \mathrm{~min}$ 113 (Takahashi et al., 2011). Numerical simulation suggests that the tsunami showed a 114 similar wave pattern close to Rikuzentakata City (Fujii et al., 2011). However, the 115 complicated shape of the Sanriku coastline influences wave height and periodicity near 116 the coast and so tsunami waves inundating the coast cannot be expected to precisely 117 follow the patterns indicated by these offshore data. 
The 2011 Tohoku-Oki tsunami largely eroded the spit in this region,

119 transporting a large amount of sandy sediments on land. Takata-Matsubara was

120 artificially designed to prevent storm and tsunami disasters, and had previously resisted

121 two major tsunamis, the 1896 Meiji Sanriku Tsunami and the 1933 Showa Sanriku

122 Tsunami (Asano et al., 2009). However, the forest was completely destroyed by the

1232011 Tohoku-Oki tsunami and only one pine tree survived, indicating the intensity of

124 the event. Tsunami waves easily spilled over and destroyed the levee behind

125 Takata-Matsubara (Figs. 3 and 4). As a result, most of the city was inundated to a

126 distance of more than $2 \mathrm{~km}$ from the shoreline, covering an area of $13 \mathrm{~km}^{2}$ from the map

127 provided by Geospatial Information Authority of Japan and the analysis by the Tsunami

128 Damage Mapping Team, Association of Japanese Geographers

129 (http://danso.env.nagoya-u.ac.jp/20110311/map/index_e.html; Fig. 2).

$130 \quad 3 . \quad$ Methodology

131 We surveyed the topographic features (erosional structures and bedforms) of

132 tsunami inundation and investigated sedimentary features of the tsunami deposits by

133 visual observation, grain-size and fabric analysis. Micropaleontological analysis was

134 also conducted to help estimate sediment sources.

\subsection{Field Survey}

We conducted approximately one week of fieldwork in Rikuzentakata City

137 between April 24-26 and June 10-12, 2011. The inundated region of Rikuzentakata

138 City can be subdivided into the main city and the Otomo area, a small settlement a few 
$139 \mathrm{~km}$ from the main town and located on flat land at the end of Hirota Peninsula (Fig. 2).

140 Our survey covered both inundated regions, mostly focusing on areas that were

141 originally rice fields. While buildings and artificial structures have complex effects on

142 tsunami waves, the rice fields are flat and are therefore expected to display the primary

143 features of tsunami deposition without artificial influences. The alignment of felled

144 power poles and crests of bedforms (dunes) were measured to estimate the flow

145 directions of tsunami waves (Fig. 4 and 5).

146 Study site locations were established using a GPS. For each observation site,

147 we examined the erosional features and the distribution of tsunami sediments and excavated pits to measure the sediment thickness and depositional structures.

149 Bulk sediment samples for grain-size and micropaleontological analysis were

150 also taken from each sampling pit. At several locations where the tsunami deposits were

151 relatively thick $(\sim 10 \mathrm{~cm})$, trenches several meters long and 10 to $40 \mathrm{~cm}$ deep were

152 excavated, and the trench walls were peeled off onto cloth by using polyurethane resin

153 (Fig. 6), in order to examine details of the sedimentary structures and conduct

154 grain-fabric analysis.

\section{$155 \quad 3.2 \quad$ Grain-size Analysis}

156 Grain-size distributions of tsunami deposits were analyzed using a Mastersizer

1572000 laser granulometer (Malvern Instruments, Malvern, UK). Before analysis, the

158 organic matter was removed using hydrogen peroxide, and sieving was performed to

159 separate sediments coarser than $2 \mathrm{~mm}$. Samples were then treated with sodium

160 hexametaphosphate as dispersant to scatter the fine sediments (Sperazza et al., 2004).

161 We converted the measured grain sizes to the phi scale $\left(\phi=-\log _{2} D\right.$ where $D$ is the 
162 particle diameter in mm). Mean grain size $\bar{\phi}$, sorting $s$, skewness $S_{k}$, and kurtosis

$163 K_{t}$ were calculated on the basis of the moment method (Folk, 1966; Harrington, 1967),

164 as follows:

$165 \bar{\phi}=\frac{\sum p \phi_{i}}{100}$

$166 s=\sqrt{\frac{\sum p\left(\phi_{i}-\bar{\phi}\right)^{2}}{100}}$

$167 \quad S_{k}=\frac{\sum p\left(\phi_{i}-\bar{\phi}\right)^{3}}{100 s^{3}}$

$168 \quad K_{t}=\frac{\sum p\left(\phi_{i}-\bar{\phi}\right)^{4}}{100 s^{4}}$

169 where $\phi_{i}$ is a representative value of each grain-size class (every 0.17 phi), and $p$ is

170 a weight fraction (in percentage) for each grain-size class. The 10th, 50th, and 90th

171 percentile grain-size values $D_{10}, D_{50}$ and $D_{90}$ respectively, were also provided for 172 each sample.

173 We measured gravels directly with a caliper and described the length of their

174 b-axes as a representative diameter for the computation of the critical flow velocity, 175 which is described in section 3.3.

\subsection{Critical Flow Velocity of Particle Motion}

The minimum estimation of the flow velocity of the tsunami wave was derived

178 from grain-size analysis and the size of the largest particles ( $>2 \mathrm{~mm}$ in b-axis diameter)

179 on the basis of the critical shear stress of initiation of particle motion with consideration

180 of mixed grain-size effect. Here, the hydraulics of oscillatory flows caused by the waves

181 are approximated by using uni-directional open-channel flows because the periodicity of

182 tsunami waves is sufficiently long to justify this approximation. Indeed, the GPS buoy 
183 measurement suggested that the periodicity of the Tohoku-Oki tsunami near

184 Rikuzentakata City was approximately $50 \mathrm{~min}$ (Takahashi et al., 2011). Therefore,

185 critical Shields values $\tau_{c}^{*}$ can be regarded as those commonly used to denote

186 conditions under which bed sediment particles are stable but on the verge of being

187 entrained in open-channel flows. A fit to the Shields data by Brownlie (1981) with

188 modification proposed by Neil and Yalin (1969) is as follows (Garcia, 2008):

189

$$
\tau_{c}^{*}=0.11 R e_{p}^{-0.6}+0.03 \exp \left(-17.77 R e_{p}^{-0.6}\right)
$$

190 where $R e_{p}$ is the particle Reynolds number, defined as $R e_{p}=\sqrt{\operatorname{Rg} D D} / v \quad(R$ :

191 submerged specific density of sediments (1.65), $g$ : acceleration due to gravity (9.81

$\left.192 \mathrm{~m} / \mathrm{s}^{2}\right), \quad D$ : sediment diameter, and $v$ : kinematic viscosity of ambient fluid), and where

193 the dimensionless Shields shear stress is defined as follows:

$194 \tau^{*}=\frac{u_{*}^{2}}{\operatorname{Rg} D}$

195 Here, $u_{*}$ denotes shear velocity. Thus, the critical Shields shear stress $\tau_{c 50}^{*}$ for

196 particles of median grain-size $D_{50}$ can be calculated by equation 5. However,

197 mixed-size grains do not act the same as when they are surrounded by grains of the

198 same size (Einstein, 1950), and the coarser grains exposed on the surface protrude more

199 into the flow, resulting in a preferentially greater drag. This exposure effect (hiding

200 effect) can be corrected by considering a power-law relationship:

$201 \quad \frac{\tau_{c i}^{*}}{\tau_{c 50}^{*}}=\left(\frac{D_{i}}{D_{50}}\right)^{-\gamma}$

202 where $\gamma$ is an empirical parameter that varies from 0.0 to 1.0 (Parker, 2005). From

203 equations 6 and 7, the critical depth-averaged flow velocity $U_{c \max }$ of the largest grain 
204 (diameter is $D_{\max }$ ) in the tsunami deposit can be calculated from the following

205 equation:

$206 U_{c \max }=C_{f}^{-\frac{1}{2}} \sqrt{\operatorname{Rg} D_{\max }\left(\frac{D_{\max }}{D_{50}}\right)^{-\gamma} \tau_{c 50}^{*}}$

207 Here, $C_{f}$ is a friction coefficient of uni-directional open-channel flows, defined as 208 follows:

209

$U_{c \max }=C_{f}^{-\frac{1}{2}} \boldsymbol{u}_{*_{c \max }}$

To estimate the critical flow velocity of initiation of particle motion, two

211 empirical parameters, $\gamma$ and $C_{f}$, must be determined. The value of $\gamma$ generally

212 ranges from 0.65 to 0.90 (Parker, 2005), and becomes zero in the case of very large

213 grains (Ramette and Heuzel, 1962); hence, we considered the value zero when

214 estimating the flow velocity of the tsunami wave from the largest grain in the deposit.

215 On the other hand, for hydraulically rough flows, the friction coefficient $C_{f}$ is given

216 by the following equation:

217

$C_{f}=\left[\frac{1}{\kappa} \ln \left(11 \frac{H}{k_{s}}\right)\right]^{-2}$

218 where $\kappa$ is the Karman constant $(\sim 0.4) ; H$, the flow thickness; and $k_{s}$, the effective

219 roughness height (Keulegan, 1938). $k_{s}$ is empirically considered to be proportional to

220 a representative sediment size $D_{90}$, such that the following relationship holds:

$221 \quad k_{s}=\alpha D_{90}$

222 The suggested value of $\alpha$ is 3.0 (Van Rijn, 1982). It is difficult to precisely estimate

223 the flow height of the tsunami wave during deposition of the bed in which the particles

224 of the maximum grain-size occurred, so we tentatively set the flow height as $10-15 \mathrm{~m}$. 
The critical flow velocity required to transport the maximum grain-size

observed at each site can be estimated using equations 5, 8, 10, and 11 . The estimated

227 velocity is, however, the minimum requirement for the tsunami waves that hit

228 Rikuzentakata City. As suggested by Hiscott (1994), the actual flow velocity could far

229 exceed the critical flow velocity of particle motion.

\section{$230 \quad 3.4 \quad$ Grain Fabric Analysis}

231 The grain fabric of vertical sections of sandy tsunami deposits was examined to

232 analyze the paleocurrent of the oscillatory flows. Trenches were excavated at several

233 localities parallel to the direction of the paleoflow which was estimated by the bedform,

234 and a peel of the trench wall was obtained using polyurethane resin and a mesh.

235 High-resolution images of the peeled sample were captured using a digital camera at

2364800 dpi. All the grains identified in the images were traced manually, and then each

237 traced grain was approximated by an ellipse, using the public-domain ImageJ program

238 (http://rsb.info.nih.gov/ij/). The locations and elongation directions of the grains were

239 obtained as quantitative image-analysis data. The location was taken as the average of the

$240 x$ and $y$ coordinates of pixels included in the traced grain, and the elongation direction

241 was obtained as the angle between the primary axis of an ellipse fitted to the grain by the

242 Hough transform and the line parallel to the $x$ axis of the image. All measured data are

243 considered to be the apparent two-dimensional characteristics of three-dimensional

244 features. The present study therefore examines only the apparent features of the tsunami

245 deposit samples, assuming equivalence to the three-dimensional structure. 


\subsection{Micropaleontology}

In order to determine the sediment source, we investigated ostracods included

248 in the onshore tsunami deposits formed by the Tohoku-Oki tsunami. Ostracods are small

249 crustacea $(0.3-30 \mathrm{~mm}$ long) with calcified valves adapted to practically every aquatic

250 environment. Thus, fossilized valves are an important paleoenvironmental indicator,

251 particularly with regard to Holocene oceanographic, climatologic, and geologic events

252 (Nelson et al., 2008). Marine podocopid ostracods are exclusively benthic crustaceans

253 that are abundant in marine sediments. Furthermore, most species show regional 254 endemism, and hence, they can be an important indicator of local bottom-water environments. The valves behave like sediment grains in the water column. We collected ostracod specimens by sieving and manual picking, and then used the modern analog technique (MAT) to infer paleoenvironmental conditions by comparing fossil ostracod assemblages in the onshore sediments with similar assemblages in the modern environment (Ikeya and Cronin, 1993). We compared Holocene ostracod assemblages sampled from 476 surface sediments of the seafloor around Japan with those recovered

261 from sediments deposited by the tsunami, approximately $4 \mathrm{~km}$ southeast of 262 Rikuzentakata City (Fig. 2).

\section{$263 \quad 3.6 \quad$ Spatial Interpolation of Measured Data}

The kriging method was employed to estimate the spatial variations in mean grain-size and thickness parameters (Burgess and Webster, 1980a,b; Kohsaka, 1998).

266 Kriging is an algorithm based on least-squares and is used to estimate the spatial

267 variation in a real-valued function; it is based on the assumption that the spatial 268 variation can be estimated from a linear combination of measured values (Kohsaka, 
269 1998). Weighting coefficients are obtained on the basis of the spatial dependence of a

270 variable; this can be represented by a semivariogram, i.e., the scatter diagram of

271 covariance with respect to spatial distance. The weighting of the running average is then

272 determined by the variogram model function, which is the fitted function to the

273 semivariogram (Burgess and Webster, 1980a). Theoretically, the covariance of spatial

274 data increases with distance and becomes a steady value at distances exceeding a

275 particular threshold (Burgess and Webster, 1980a,b; Kohsaka, 1998). This limited

276 distance is the range within which the data indicates spatial dependence. The spatial

277 dependencies of the data are also shown in the estimation variances, which provide a

278 measure of the uncertainty in the interpolation values. When directional anisotropy was

279 detected in semivariograms, geometric anisotropy was removed by applying an affine

280 transformation to the distances of the sample sites.

281 Spatial distributions of deposition thickness and mean grain-size data were

282 interpolated across the entire surveyed region. Semivariograms were calculated from the

283 measured data, and variogram models were fitted using the weighted least-squares

284 method. Both the interpolated values and estimation standard errors were shown as 285 color images.

286 4. Results

\subsection{Topographic Features and Bedforms}

In regions up to approximately $500 \mathrm{~m}$ from the shoreline, erosion by the

tsunami dominated where flute-like depressions with erosional fringes were observed 
290 (Fig. 4C), ranging in diameter from $10 \mathrm{~cm}$ to several meters. Deformed sedimentary

291 features or upward injection of sands that are generally associated with liquefaction

292 were not observed. Although detailed topographic measurements were not conducted,

293 the severe erosion that removed the pine forest on the spit appeared to extend to a depth

294 of around 0.5 to $1 \mathrm{~m}$. Analysis of aerial photographs (Fig. 3) indicated that the region

295 eroded by the tsunami was approximately $3.5 \times 10^{5} \mathrm{~m}^{2}$.

All power poles observed in Rikuzentakata City were bent by tsunami

297 inundation flows (Fig.4B), and the orientation of the fallen poles indicated that the

298 flooding direction was mostly northward within the main city area, whereas several

299 poles in the main city also indicate southward backwash currents (Fig. 7).

300 Tsunami deposits were distributed across the entire inundated area of

301 Rikuzentakata City (Figs. 5 and 6). In most areas, a uniform thickness generally draped

302 the natural topography. However, dunes were occasionally formed by flooding or

303 backwash currents in both the main city and the Otomo areas (Fig. 5A). Dunes are

304 composed of coarse sand and pebbles, with wavelengths generally ranging from 1 to 10

$305 \mathrm{~m}$. The largest dune was composed of cobble-sized gravels and was observed in the

306 Otomo area (Fig. 5A); it had a wavelength of $10 \mathrm{~m}$ and was $30-40 \mathrm{~cm}$ high. Flow

307 directions suggested by dune crests and foresets were southwestward $\left(\mathrm{N} 230^{\circ}\right)$ in the 308 main city area, and southeastward $\left(\mathrm{N} 144^{\circ}\right)$ in the Otomo area.

$309 \quad 4.2 \quad$ Thickness Variation

310 The field survey and kriging interpolation helped determine the thickness of the

311 tsunami deposits in Rikuzentakata City (Fig. 8). The transported sediment started to be

312 laid down approximately $500 \mathrm{~m}$ from the shoreline, and attained a maximum thickness 
$313(31.5 \mathrm{~cm})$ within the next $100 \mathrm{~m}$. The thickness of the deposits then gradually decreased

314 landward; however, local variations in sediment thickness were observed in relation to

315 topographic depressions or elevations. The tsunami deposits continued to the maximum 316 extent of inundation, where the thickness of muddy deposits ranged from 0.5 to $2 \mathrm{~cm}$ 317 (Fig. 8; Table 2).

318 As the tsunami deposits varied in thickness throughout Rikuzentakata City, the

319 total deposition was calculated by summing the interpolated distribution, giving an 320 estimate of $6.1 \times 10^{5} \mathrm{~m}^{3}$ transported material (standard error $1.5 \times 10^{3} \mathrm{~m}^{3}$ ).

\subsection{Sedimentary Structures and Units}

Based on observation of sedimentary structures in pits and trenches, it was determined that the tsunami deposits in Rikuzentakata City were composed of one to four sedimentary units, identified by distinctive sedimentary structures and grain-size changes (Figs. 9, 10 and 11). Each sedimentary unit ranged from 1 to $10 \mathrm{~cm}$ in thickness, and showed a flat, layer-like geometry (Figs. 6, 9, 10 and 11). Each unit typically consisted of inverse-graded sand overlain by normally graded or gravelly sand (Fig. 9). The normally graded sub-unit was generally thicker than the inverse-graded one. The

329 boundary between these two sub-units was often a sharp erosional surface, and 330 occasionally the inverse-graded sub-unit was truncated. A thin mud drape $(<1 \mathrm{~cm})$ occurred on the top of the normally graded division (Fig. 9). Each unit commonly showed parallel lamination and, less frequently, current ripple cross-lamination could be observed (Fig. 9). The lowermost unit was generally the thickest and coarsest, and often

334 contained large clasts, such as pebbles or cobbles, within sands (Fig. 10). The upper units showed upward thinning and fining, and large clasts were rare in these units. 
Each unit in the deposit showed evidence that it was formed under a

337 unidirectional runup or backwash current of the tsunami wave (Fig. 11). Grain fabric

338 analysis indicated that the flow direction was constant within an inverse-graded to

339 graded unit and varied from runup to the backwash current at the boundary between

340 units (Fig. 12). The paleocurrent direction shown by cross-lamination and dunes is

341 consistent with the grain-fabric data (Figs. 10, 11 and 12).

342 The thickness and number of units in the deposits decreased landward, and the

343 sandy sub-unit finally disappeared near the edge of tsunami inundation (Fig. 10 and 11),

344 although mud drapes were continuous. Flow-parallel variations in the thickness and

345 sedimentary structures of units were examined at two transects, one is in the eastern

346 region of the main city area (Transect 1) and another is in the Otomo area (Transect 2)

347 (Fig. 11). In Transect 1, the tsunami deposit was composed of two inverse-graded to

348 normally graded units at the seaward end (Fig. 11). The lower unit was a 15-cm-thick

349 very coarse pebbly sand, and showed thinning and fining landward. The upper unit was

350 a 5-cm-thick medium sand, which pinched out within $500 \mathrm{~m}$. In Transect 2, three units

351 occurred at the upstream end of the runup current (Fig. 11). Grain-fabric analysis and

352 cross-lamination suggest that the first and third units were formed by the southeastward

353 runup current (Fig. 12), and that the second unit was formed by the northwestward

354 backwash current. The first unit was thick and was the coarsest, containing shell

355 fragments at its top. This unit showed fining and thinning down current, but continued

356 until the downstream end. The second unit was also thick, but pinched out within

357 approximately $500 \mathrm{~m}$. The third unit was relatively thin and showed fining and thinning 358 down current. 
4.4 Spatial Variation in Grain Size and Critical Flow Velocity for Particle

360

361

362

363

364 Motion

Analysis of spatial variation in grain sizes indicated landward fining (Fig. 13;

Table 2). Since the granulometric properties of the tsunami deposits vary vertically, we plotted data obtained from the lowermost, coarsest unit in each site (Fig. 13). The interpolated data of mean grain-size reveal that the center of the main city area was covered by sandy deposits (Fig. 13), whereas samples taken from the northern end of the inundation area were composed of muddy sediments. Thus, sand-sized sediments diminished before the limit of the inundation area. Kriging interpolation of spatial variation of mean grain-size suggests that the muddy sediments were transported $2 \mathrm{~km}$ further than the distribution limit of the sandy deposits (Fig. 13).

Analysis of the critical flow velocity of the largest particles revealed that the first flood wave exceeded $2.4 \mathrm{~m} / \mathrm{s}$ at minimum (Fig. 14). A total of 21 sites were examined, where gravels occurred in the lowermost unit of the tsunami deposit; the estimated critical flow velocity ranged from 0.9 to $2.4 \mathrm{~m} / \mathrm{s}$ when the flow height was set to $10 \mathrm{~m}$. The critical flow velocity ranged from 0.9 to $2.7 \mathrm{~m} / \mathrm{s}$ when the flow height was set to the estimated maximum inundation height of $15 \mathrm{~m}$. Higher critical flow velocity $(2.4$ or $2.7 \mathrm{~m} / \mathrm{s})$ was detected in the middle of the inundation area, slowing towards the margins (0.9 m/s; Fig. 14).

\subsection{Ostracods}

The ostracod assemblages were recovered from sediments deposited by the tsunami in the main city and Otomo area (collected at Locs. 19, 60, 94, 95 and 96 of Fig. 2 on April 25; Fig. 15 and Table 1). A sample taken at Loc. 60 contained abundant 
382 ostracod speciments, and was characterized by inner bay species, such as

383 Bicornucythere bisanensis (Fig. 15B-1), Nipponocythere bicarinata (Fig. 15B-2),

384 Spinileberis quadriaculeata (Fig. 15B-3), and Cytheromorpha acupunctata (Fig. 15B-4).

385 It also contained some rocky shore species (Aurila corniculata, Xestoleberis hanaii)

386 (Table 1). Some of the ostracod valves of the sample were well preserved (Figs. 15B)

387 and translucent. Moreover, the soft parts were preserved in one B. bisanensis specimen

388 (Fig. 15B-1). However, many of the ostracod valves were opaque and fragmented,

389 indicating that the ostracod assemblage in the sample was probably derived from a

390 thanatocoenosis on the seafloor. Thus, it was appropriate to use MAT to compare the

391 assemblage of the sample at Loc. 60 with Holocene ostracod thanatocoenoses such as

392 those obtained from around Japan.

393 By applying MAT, we determined that the ostracod assemblage in the sample

394 of Loc. 60 was most similar to that of sample OK 28 from Osaka Bay; which had been

395 collected from a water depth of $9 \mathrm{~m}$ (Fig. 15A).

\section{5. Discussion}

$397 \quad 5.1 \quad$ Use of the Tsunami Deposits in Rikuzentakata City for the Identification of Older Events

This study revealed that the tsunami deposits in Rikuzentakata City generally

400 consisted of multiple units that represented a discrete runup or backwash flow, as 401 described in Section 5.3 (Figs. 10, 11 and 16). Thus, for example, two inundations 402 produced four units (two runup and two backwash). This feature of the tsunami deposit 
403 is quite different from that on the Sendai Plain, where multiple units were not obvious

404 (Goto et al., 2011). This difference could be attributed to differences in the tsunami 405 hydrographs and local topography.

406 Each unit was characterized by initial inverse grading and successive normal 407 grading that correspond to the accelerating and decelerating stages of the runup or 408 backwash flow respectively (Fig. 16). Multiple units with inverse- to normal-grading 409 were also reported from the 2004 Indian Ocean Tsunami deposits in Thailand (Naruse et 410 al., 2010) and other coastal environments (e.g., Kon'no, 1961; Shi et al., 1995; Benson 411 et al., 1997; Dawson \& Smith, 2000; Gelfenbaum \& Jaffe, 2003; Moore et al., 2006; 412 Nanayama \& Shigeno, 2006), suggesting the general applicability of this facies model 413 of the multiple-bedded terrestrial tsunami deposits described here. Each unit of 414 multilayered tsunami deposits have often been attributed to a discrete wave (e.g., 415 Kon'no, 1961; Clague et al., 2000) or one set of runup/backwash currents of a tsunami 416 (e.g., Moore \& Moore, 1984; Nishimura \& Miyaji, 1995; Nanayama \& Shigeno, 2006).

417 Sedimentary features within multiple-bedded tsunami deposits are often complicated 418 (e.g., Moore et al., 2006) and their formative processes have been interpreted to be a 419 consequence of the multiple waves of tsunamis (e.g., Fujiwara, 2007). A characteristic 420 feature of tsunamis is the turnover of unidirectional current due to long wave period 421 (several minutes to tens of minutes) that involves acceleration, deceleration and turnover stages.

The runup units are generally thicker than the backwash units probably because of the asymmetric behavior of tsunami waves and the availability of source sediments 425 (Naruse et al., 2010). The tsunami waves run up with relatively uniform flow directions, 426 whereas those of the backwash currents are generally concentrated and localized 
427 (Umitsu, 2006; Dodd et al., 2008). This asymmetric behavior of tsunami waves is 428 commonly observed in various environments (Umitsu, 2006; Naruse et al., 2010), and 429 can explain the fact that backwash units in the onshore tsunami deposit are often absent 430 or distributed only locally.

431 The importance of understanding the internal subunits of each unit in a tsunami 432 deposits is critical for the identification of the runup unit. Naruse et al. (2010) proposed 433 a facies model of tsunami deposits in which the basal inverse graded divisions (subunit 434 I) are produced during the waxing stage of the tsunami runup or backwash flows but 435 they are easily lost due to subsequent erosion (Fig. 16). An internal erosion surface 436 (IES) often develops between the inverse and normal graded subunits. As a result, 437 tsunami deposits are generally composed of graded units (subunit G) that are deposited 438 in the waning stage of flow and therefore have a greater preservation potential. In the 439 case of the runup flow, the stagnant stage of the tsunami wave forms silty mud drapes 440 (subunit S). Thus, it was suggested that the sequence ideally containing units I-G-S 441 corresponds to the runup flow and the sequence containing units I-G corresponds to the 442 backwash flow although there are large variations due to local erosion and deposition 443 (Fig. 16). The model assumes that deposition and erosion by tsunami waves are mostly 444 caused by spatial differences in the rate of sediment transport, and the sites of 445 deposition and erosion show a patchy distribution when the flow velocity field is 446 remarkably non-uniform. Thus, remarkable lateral variations in sedimentary structures 447 in a tsunami deposit can mostly be explained by localized erosional and depositional 448 processes.

Without this subunit I-G-S model (Naruse et al., 2010), the flow units in a 450 tsunami deposit may be misinterpreted. For example, the tsunami deposit in Loc. 93 
appeared to be composed of 5-6 subunits that were bounded by mud drapes or erosional surfaces (Fig. 16), but the grain-fabric analysis suggested that the deposit actually consisted of three flow-units ( 2 runup and 1 backwash units) (Fig. 11 and 12). Erosional surfaces are intercalated within a flow unit due to the waxing of the runup or backwash flow, and the true unit boundaries are between the normal- and inverse-graded subunits (subunits G to I) or silty mud drapes (subunit $\mathrm{S}$ ).

The trends of landward fining and thinning of each unit and a decrease in the number of units are also common features in various terrestrial environments (e.g.,

459 Fujino et al., 2010). The landward fining trend of each unit that differentiates the run-up 460 limit of the sandy and muddy sediments is an especially significant feature for reconstructing inundation areas based on the distribution of ancient tsunami deposits. Sandy tsunami deposits were distributed widely in the main city area, whereas muddy deposits ( $<4$ phi on average) occurred near the margins of the inundation area (Fig. 13). Kriging interpolation of the mean grain-size of the deposits revealed that the tsunami

465 can extend more than $2 \mathrm{~km}$ from the run-up limit of the sandy deposits (Fig. 13).

466 Therefore, it is suggested that precise reconstruction of tsunami inundation from

467 geological record requires the identification of muddy tsunami deposits (Goto et al., 468 2011). While these may be quite difficult to distinguish from surrounding soils, 469 Chagué-Goff et al. (in press this issue) show that geochemical markers can successfully 470 differentiate between fine grained sediments of marine or terrestrial origin. It should 471 also be noted that the number of data control points is small in the northern region of the 472 study area so that the result of the Kriging method is similar to that of linear 473 interpolation. Thus, future analysis with a larger number of data control points is needed 474 to confirm the actual transition point between sandy and muddy tsunami deposits. In our 
475 area, the number of internal sedimentary units also decreased landward as a result of

476 landward thinning of each unit. It is therefore recommended that the seaward end of a

477 tsunami deposit should be studied when attempting to estimate the number of waves 478 associated with inundation.

\subsection{Reconstruction of Behavior of the Tohoku-Oki tsunami in Rikuzentakata} City

The behavior of the Tohoku-Oki tsunami in Rikuzentakata City reconstructed from the analysis of tsunami deposits reveals that at least two waves inundated the city with velocities exceeding $2.4 \mathrm{~m} / \mathrm{s}$. This estimation provides minimum value of the flow velocity, and future study with evidence such as video footage or eye-witness accounts will reveal the merits and limitations of this analysis of the wave properties from the sediments. The analysis of the sediment flux and micropaleontological evidence suggests that erosion of the seafloor of Hirota Bay may have occurred and the resulting sediments probably transported on land.

In Transects 1 and 2, the basal, flooding flow, unit could be traced to the

490 landward end of both transects (Fig. 11). The first backwash flow unit occurred in the

491 seaward half of Transects 2 , and pinched out near its center. The second runup flow unit was also continuous in Transect 2, whereas it was no longer visible in the center of Transect 1. Although the correlation between the sedimentary units in the main city area was difficult due to the complexity of sedimentary units, a maximum of four runup units could be recognized, suggesting that two or more waves also inundated this region. As described above, data from a GPS buoy located approximately $15 \mathrm{~km}$ offshore indicates 
wave was the largest. The first runup flow unit of the tsunami deposit in Rikuzentakata

499 City is the thickest, and therefore, it is reasonable to suggest that this unit may be correlated with the first inundating wave. With regard to successive waves, it is difficult to correlate these with flow units. Records from the GPS buoy indicate that the second and fourth waves were relatively high (approximately $2 \mathrm{~m}$ in height), whereas others were relatively small (less than $1.5 \mathrm{~m}$ in height). Hence, we tentatively correlate the

504 second flooding flow unit to the second or the fourth wave, although future

505 investigation using methods such as numerical simulation would seem necessary to confirm this correlation.

The analysis of sediment flux implies that the tsunami deposit in Rikuzentakata

City included material not only from terrestrial erosion but also subaqueous erosion in

Hirota Bay. The paleontological evidence clearly indicates that the sediment source of the tsunami deposit was at least partially from Hirota Bay. Bathymetric data indicate a

511 water depth of $9 \mathrm{~m}$. The total amount of sediment deposited on land was estimated to be

$5126.1 \times 10^{5} \mathrm{~m}^{3}$ (standard error: $1.5 \times 10^{3} \mathrm{~m}^{3}$ ). If all sediments were provided from the

513 sandy spit eroded by the first tsunami wave $\left(3.5 \times 10^{5} \mathrm{~m}^{2}\right)$, the average depth of

514 erosional truncation would be approximately $1.7 \mathrm{~m}$. Although the exact values should

515 be determined by a future survey, this depth of erosion seems unlikely on the basis of

516 visual observations. We infer that the erosional depth on the beach was less than $1 \mathrm{~m}$

517 (Fig. 4C and 4D), and that nearly half of the sediments were transported from the seafloor of Hirota Bay or from further offshore. Indeed, muddy sediments were widely

519 distributed near the landward end of the inundation area, suggesting another sediment

520 source of fine-grained sediments was available. Muddy sediments can be also sourced

521 from the rice paddy fields, but erosion in the study area was limited to the coastal area 
522

523

524

525

where rice fields were not present (Fig. 3). Trench examination suggested that the rice paddy fields were not markedly eroded (e.g. Fig. 6a), indicating a likely marine source for the fine-grained tsunami deposits.

\section{Conclusion}

The 2011 Tohoku-Oki tsunami deposited a large amount of sediments on land.

528 A field survey at Rikuzentakata City, northeastern Japan, provided tsunami inundation characteristics for this region and a facies model of deposition on the bay-head deltas of estuarine systems.

(1) The tsunami deposit in Rikuzentakata City generally consisted of one- to four units that represent a discrete runup or backwash flow. Each unit was characterized by initial inverse grading (subunit I) and successive normal grading (subunit G), which

534 correspond to the accelerating and decelerating stages of the flow, respectively. Between

535 subunit I and G, an internal erosion surface often developed in response to the stage in 536 which the flow reached maximum shear velocity, truncating the underlying 537 inverse-graded subunit I. In case of the runup flow unit, the silty, fine-grained drapes

538 (subunit S) overlaid the graded interval (subunit G). Features of multiple units with inverse-to-normal graded divisions are similar to the facies model for tsunami deposits

540 in coastal plains, suggesting the general applicability of the model to multiple-bedded, 541 terrestrial tsunami deposits.

(2) Correlation between the sedimentary structures and analysis of the grain

543 fabric of the tsunami deposit revealed that the Tohoku-Oki tsunami inundated 
544 Rikuzentakata City at least twice, and that flow velocity exceeded $2.4 \mathrm{~m} / \mathrm{s}$.

545 Paleontological analysis of the sediment provenance and kriging estimation of the total

546 volume of the tsunami deposits indicate that the sediments were derived not only from

547 the eroded beach sands but also from the seafloor of Hirota Bay or more pelagic 548 regions.

549 All the inferences obtained from the study of tsunami deposits in Rikuzentakata

550 City can be used to refine future studies such as the development of numerical models.

551 Although offshore tsunami hydrograph data are available, the complicated shape of

552 Sanriku Coast affected the wave height and periodicity near the coast. Therefore,

553 hydrodynamic numerical models of tsunamis are important for future disaster

554 prevention planning, and data from tsunami deposits (such as the number of waves and

555 minimum flow velocities of runup flows) provide important constraints for model

556 verification. The amount and sources of sediments transported by the tsunami are also

557 important factors for model verification. Morphodynamic models require sediment

558 entrainment functions of bedload and suspended load for the calculation of landform

559 developments, and numerous types of empirical functions have been proposed by

560 various methods (e.g., Garcia and Parker, 1991). The choice of sediment entrainment

561 functions should be tested by natural cases of complicated shorelines such as the

562 tsunami deposits in Rikuzentakata City.

\section{Acknowledgments}

564 This survey was conducted as part of the research of The 2011 Tohoku

565 Earthquake Tsunami Joint Survey Group (www.coastal.jp/tsunami2011). We gratefully 
566

567

568

569

acknowledge their sincere contributions. We are grateful to Hitoshi Shibuya and Takuya Matsuzaki for their help with field sampling and grain-size measurements at Kochi Core Center. This study is dedicated to all those affected by the March 11, 2011 earthquake.

\section{References}

Abe, T., Goto, K., Sugawara, D., in press this issue Relationship between the maximum extent of tsunami sand and the inundation limit of the 2011 Tohoku-Oki tsunami on the Sendai Plain, Japan. Sedimentary Geology, doi:10.1016/j.sedgeo.2012.05.004.

Asano, T., Matsumoto, C., Nagano, A., 2009. Functional Assessment on Coastal Forests in Japan as Tsunami Barrier Facilities. Journal of Hydraulic, Coastal and Environmental Engineering (JSCE) B2-65, 1311-1315. (in Japanese with English abstract)

Benson, B.E., Grimm, K.A. \& Clague, J.J. 1997. Tsunami deposits beneath tidal marshes on northwestern Vancouver Island, British Columbia. Quaternary Research 48, 192-204.

Brownlie, W.R., 1981. Prediction of flow depth and sediment discharge in open channels. Report No. KH-R-43A, Keck Laboratory of Hydraulics and Water Resources, California Institute of Technology, Pasadena, California.

Burgess, T.M., Webster, R., 1980a. Optimal interpolation and isarithmic mapping I. The semi-variogram and punctual kriging. European Journal of Soil Science 31, $315-331$. 
Burgess, T.M., Webster, R., 1980b. Optimal interpolation and isarithmic mapping. II. Block kriging. European Journal of Soil Science 31, 505-524.

Chagué-Goff, C., Andrew, A., Szczuciński, W., Goff, J., Nishimura, Y. in press this issue. Geochemical signatures up to the maximum inundation of the 2011 Tohoku-oki tsunami - implications for the 869 AD Jōgan and other palaeotsunamis. Sedimentary Geology. doi:10.1016/j.sedgeo.2012.05.021

Chida, N., Matsumoto, H., Obara, S., 1984. Recent Alluvial Deposit and Holocene Sea level Change on Rikuzentakata Coastal Plain, Northeast Japan. Tohoku-Chiri 36, 232-239. (in Japanese with English abstract).

Clague, J.J., Bobrowsky, P.T., Hutchinson, I., 2000. A review of geological records of large tsunamis at Vancouver Island, British Columbia, and implications for hazard. Quaternary Science Reviews 19, 849-863.

Dawson, S., Smith, D.E., 2000. The sedimentology of Middle Holocene tsunami facies in northern Sutherland, Scotland, UK. Marine Geology 170, 69-79.

Dodd, N., Stoker, A.M., Calvete, D., Sriariyawat, A., 2008. On beach cusp formation. Journal of Fluid Mechanics 597, 145-169.

Einstein, H.A., 1950. The Bedload Function for Bedload Transportation in Open Channel Flows. Technical Bulletin No. 1026 , U.S.D.A., Soil Conservation Service, $1-71$.

Folk, R.L., 1966. A review of grain-size parameters. Sedimentology 6, 344-359.

Fujii, Y., Satake, K., Sakai, S., Shinohara, M., Kanazawa, T., 2011. Tsunami source of the 2011 off the Pacific coast of Tohoku Earthquake. Earth Planets Space 63, 
613 Fujino, S., Naruse, H., Matsumoto, D., Sakakura, N., Suphawajruksakul, A., Jarupongsakul, T., 2010. Detailed measurements of thickness and grain size of a widespread onshore tsunami deposit in Phang-nga Province, southwestern Thailand. Island Arc 19, 389-398.

617 Fujiwara, O., 2007. Major contribution of tsunami deposit studies to Quaternary Research. The Quaternary Research (Daiyonki kenkyu) 46, 293-302.

Garcia, M.H., 2008. Sediment Transport and Morphodynamics. In: Garcia M.H. (Eds.), Sedimentation engineering: processes, management, modeling, and practice. American Society of Civil Engineers, Virginia, USA, pp. 21-163.

García, M.H., Parker, G., 1991. Entrainment of Bed Sediment into Suspension. Journal of Hydraulic Engineering, ASCE 117, 414-435.

Gelfenbaum, G., Jaffe, B., 2003. Erosion and sedimentation from the 17 July, 1998 Papua New Guinea Tsunami. Pure and Applied Geophysics 160, 1969-1999.

Goto, K., Chagué-Goff, C., Fujino, S., Goff, J., Jaffe, B., Nishimura, Y., Richmond, B., New insights of tsunami hazard from the 2011 Tohoku-oki event. Marine Geology 290, 46-50.

630 Goto, K., Chagué-Goff, C., Goff, J., Jaffe, B. (submitted this issue). The future of 631 tsunami research following the 2011 Tohoku-oki event. Sedimentary Geology

633 Harrington, R.F., 1967. Field Computation by Moment Methods, 1st ed. The Macmillan Co., New York.

635 Hiscott, R.N., 1994. Loss of capacity, not competence, as the fundamental process 
636

637

638

639

640

641

642

643

644

645

646

647

648

649

650

651

652

653

654

655

656

657

658

659

governing deposition from turbidity currents. Journal of Sedimentary Research 64, 209-214.

Ikeya, N., Cronin, T.M., 1993. Quantitative analysis of Ostracoda and water masses around Japan: application to Pliocene and Pleistocene paleoceanography. Micropaleontology 39, 263-281.

Keulegan, G.H., 1938. Laws of turbulent fl ow in open channels. Journal National Bureau of Standards, Research Paper 1151, 707-741.

Kohsaka, H., 1998. Kriging and its Geographic Applications. Bulletin of Nihon University College of Humanities and Sciences 34, 27-35.

Kon'no, E., 1961. Geological observations of the Sanriku coastal region damaged by Tsunami due to the Chile Earthquake in 1960. Contributions from the Institute of Geology and Paleontology, Tohoku University 52, 1-40. (in Japanese with English abstract)

Moore, J.G., Moore, G.W., 1984. Deposit from a giant wave on the island of Lanai, Hawaii. Science 226, 1312-1315.

Moore, A., Nishimura, Y., Gelfenbaum, G., Kamataki, T., Triyono, R., 2006. Sedimentary deposits of the 26 December 2004 tsunami on the northwest coast of Aceh, Indonesia. Earth, Planets and Space 58, 253-258.

Mori, N., Takahashi,, T., Yasuda, T., Yanagisawa, H., 2011. Survey of 2011 Tohoku earthquake tsunami inundation and run-up, Geophysical Research Letters 38, doi:10.1029/2011GL049210.

Nanayama F., Shigeno, K., 2006. Inflow and outflow facies from the 1993 tsunami in southwest Hokkaido. Sedimentary Geology 187, 139-158.

Nanayama, F., Satake, K., Furukawa, R., Shimokawa, K., Atwater, B.F., Shigeno, K. \& 
660

661

662

663

664

665

666

667

668

669

670

671

672

673

674

675

676

677

678

679

680

681

682

683

Yamaki, S., 2003. Unusually large earthquakes inferred from tsunami deposits along the Kuril trench. Nature 424, 660-663.

Naruse, H., Fujino, S., Suphawajruksakul, A., Jarupongsakul, T., 2010. Features and formation processes of multiple deposition layers from the 2004 Indian Ocean Tsunami at Ban Nam Kem, southern Thailand. Island Arc 19, $399-411$.

National Police Agency of Japan, 2012. http://www.npa.go.jp/archive/keibi/biki/

higaijokyo_e.pdf.

Neill, C.R., Yalin. M.S., 1969. Qualitative defi nition of beginning of bed movement. Journal of the Hydraulics Division, ASCE 95, 585-587.

Nelson, A.R., Sawai, Y., Jennings, A.E., Bradley, L.A., Gerson, L., Sherrod, B.L., Sabean, J., Horton, B.P., 2008. Great-earthquake paleogeodesy and tsunamis of the past 2000 years at Alsea Bay, central Oregon coast, USA. Quaternary Science Reviews 27, 747-768.

Nettles, M., Ekstrom, G., Koss, H.C., 2011. Centroid-moment-tensor analysis of the 2011 off the Pacific coast of Tohoku Earthquake and its larger foreshocks and aftershocks. Earth, Planets and Space, 63, 519-523.

Nishimura, Y., Miyaji, N., 1995. Tsunami deposits from the 1993 southwest Hokkaido earthquake and the 1640 Hokkaido Komagatake eruption, northern Janap. Pure and Applied Geophysics 144, 719-733.

Parker, G., 2005. ID morphodynamics of rivers and turbidity currents. <http://cee.uiuc.edu/people/parkerg/morphodynamics_e-book.htm>.

Ramette, M.M., Heuzel, M.M., 1962. A study of pebble movoment in the Rhone by means of tracers. La Houille Blanche, Special A., 389-398. 
684 Shi, S., Dawson, A.G., Smith, D.E., 1995. Coastal sedimentation associated with the 685 December 12th 1992 Tsunami in Flores, Indonesia. Pure and Applied

686 Geophysics 144, 525-536.

687 Sperazza, M., Moore J.N., Hendrix M.S., 2004, High-Resolution Particle Size Analysis 688 of Naturally Occurring Very Fine-Grained Sediment Through Laser Diffractometry. Journal of Sedimentary Research 74, 736-743.

690 Stimpson, I., 2011. Japan’s Tohoku Earthquake and Tsunami. Geology Today 27, 96-98.

691 Switzer, A.D., Jones, B.G., 2008. Large-scale washover sedimentation in a freshwater

692

693

694

695

696

697

698

699

700

701

702

703 lagoon from the southeast Australian coast: sea-level change, tsunami or exceptionally large storm? The Holocene 18, 787-803.

Takahashi, S., Toda, K., Kikuchi, Y., et al., 2011. Urgent Survey for 2011 Great East Japan Earthquake and tsunami disaster in ports and coasts. Technical Note of the Port and Airport Research Institude 1231, Port and Airport Research Institute, Japan, Yokosuka, pp. 1-200.

Umitsu, M., 2006. Spatial distribution of tsunami flow and deposits of tsunami on the Nam Khem Plain, southern Thailand. Chikyu Monthly 28, 546-552. (in Japanese).

Van Rijn, L.C., 1982. Equivalent roughness of alluvial bed. Journal of the Hydraulic Division, ASCE $\quad 108,1215-1218$. 
704

705

706

707

708

709

710

711

712

713

714

715

716

717

718

719

720

721

722

723

724

725

\section{Figure captions}

Figure 1. Index maps of study area. A: Map of northeastern Japan showing epicenter of Tohoku Oki earthquake. B: Study area.

Figure 2. Locality maps of the study area. Estimation of inundation area is based on the Maps of the Area hit by the Tsunami of 11 March 2011, Northeast Japan by Tsunami Damage Mapping Team, Association of Japanese Geographers (http://danso.env.nagoya-u.ac.jp/20110311/map/index_e.html).

Figure 3. Airphotos of Rikuzentakata City provided by Geospatial Information Authority of Japan. A: Airphoto taken before the tsunami (2010). White arrows indicate Takata-Matsubara pine forest located on a wave-dominated spit. B: Airphoto taken after the tsunami (March 13th 2011). Yellow dashed lines indicate regions where erosional processes of the tsunami dominated. The photo shows Takata-Matsubara was eroded by the tsunami.

Figure 4. Photographs taken at Rikuzentakata City. A: Broken building in Rikuzentakata City. B: Poles flattened by the tsunami runup flow. C: Flute-like erosional features. Scale is $1 \mathrm{~m}$. D: Collapsed coastal levee and Takata-Matsubara pine forest.

Figure 5. Photographs showing features of the tsunami deposit at Rikuzentakata City. A: Dunes formed by backwash flow. B: Garbage accumulated at the maximum extent of tsunami inundation area. C: Rice fields covered by tsunami deposits. D: Tsunami deposits in the parking area (Loc. 111).

Figure 6. Pictures of flow-parallel vertical sections of tsunami deposits in Rikuzentakata 
City. Left is the seaward direction in all pictures. A: Wall of trench excavated at Loc. 31. Boundary between the tsunami deposit and the original surface of the rice field is smooth and shows no erosional feature. B: Tsunami deposit peeled off from a trench wall onto cloth using polyurethane resin at Loc 14 . Scale bar is $5 \mathrm{~cm}$. C: Tsunami deposit peeled off from a trench wall at Loc 93. Cross lamination shows that the middle part of this deposit was formed by backwash flow. Scale bar is $10 \mathrm{~cm}$.

Figure 7. Directions of tsunami inundation flow measured from damaged artificial objects such as bent power poles. Runup currents are dominant.

Figure 8. Thickness distributions of the tsunami deposit. A: Bubble plot of thickness of the tsunami deposit at each sampling location. B: Kriging estimation of spatial thickness distribution of the tsunami deposit in Rikuzentakata City. White dashed line indicates distribution limit of sandy deposits. C: Standard error of the result of the kriging estimation.

Figure 9. A typical example of the vertical variation of the tsunami deposit (Loc. 11E) in mean grain-size. The deposit is characterized by inverse- to normal-graded multiple units, although it lacks a silty subunit (subunit S). Bars indicate the standard deviation of grain-size distribution at each interval.

Figure 10. Columnar sections showing cross profile of tsunami sand sheets in the main city area of Rikuzentakata City. The locations of the sections are indicated in Figure 2. The top of each columnar section corresponds to the local ground surface. Reconstructions of paleo-flow directions are based on grain fabric (Loc.19) and cross-laminations (Loc. 11W). Scale bars are $10 \mathrm{~cm}$.

Figure 11, Stratigraphic sections on flow-parallel transects showing a cross profile of 
tsunami sand sheets in Otomo Area of Rikuzentakata City. The locations of the two transects are indicated in Figure 2. The top of each section corresponds to the local ground surface. Scale bars are $10 \mathrm{~cm}$.

Figure 12. Rose diagrams showing results of grain fabric analysis of the tsunami deposit in vertical sections. Imbrication angles of sand-sized grains at flow-parallel vertical sections were examined and the runup and backwash flow units were identified at each locality.

Figure 13. Mean grain-size distribution of the basal unit of the tsunami deposit. A: Bubble plot of mean grain-size of the tsunami deposit at each sampling location. B: Kriging estimation of spatial distribution of mean grain-size. C: Standard error of the kriging estimation results.

Figure 14 Bubble plot of the critical flow velocity of gravels. The runup or backwash flow of the tsunami in Rikuzentakata City must exceed these values at each sampling point.

Figure 15. A: Map of Japan showing locations of the study area and the reference site OK28. B: Scanning electron microscope images of characteristic species recovered from sample c: (1) Bicornucythere bisanensis (2) Nipponocythere bicarinata; (3) Spinileberis quadriaculeata; (4) Cytheromorpha acupunctata.

Figure 16 Schematic model of the formation process of multiple-bedded tsunami deposits. A: Typical variation of the tsunami sequence that was frequently observed in Rikuzentakata City. Subunits I, G and S indicate inverse-graded, graded, and silty subunits. The ideal tsunami sequence formed by a single wave is composed of two units, consisting of subunits I-G-S-I-G. At the 
turnover stage from backwash to run-up, there is no ponding of stagnant water on land so that a thick, silty subunit (subunit S) is not found at the top of the backwash depositional unit. Inverse-graded subunits of runup flow units and 1st backwash-flow unit were lost due to erosion. B: Schematic formative process of the inverse- to normal-graded bedding in the tsunami deposit. Flow conditions for processes 1-3 are shown in Figure 16A. An internal erosion surfaces (IES) often develops between the inverse and normal graded subunits.

782

783 Table 1. Ostracods species observed in the tsunami deposits.

784 Table 2. Result of grain-size analysis by laser granulometer. All grain-size values are 785 shown in phi scale. Max. $G$ is the maximum grain size. 

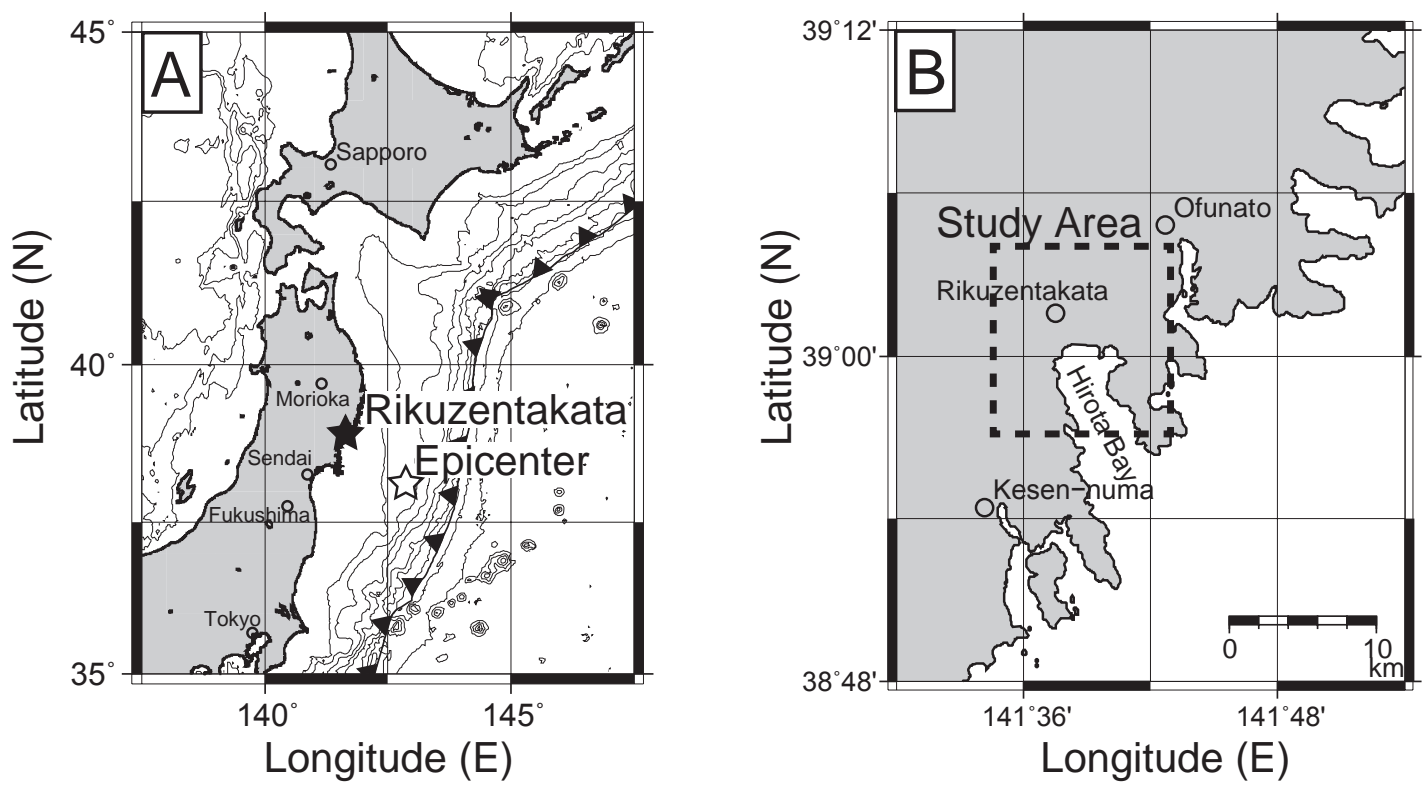

Naruse et al. Fig. 1 

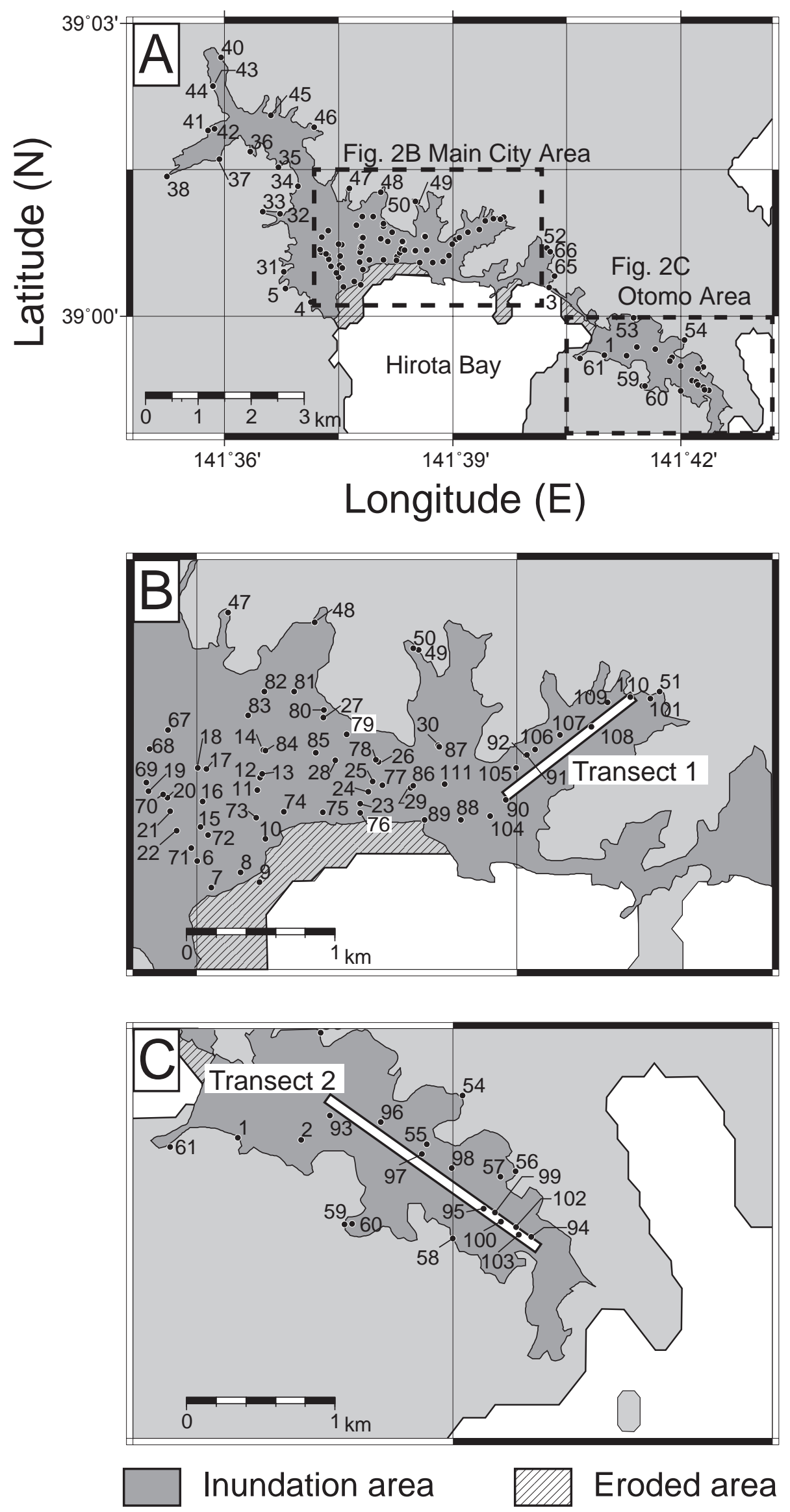

Naruse et al. Fig. 2 

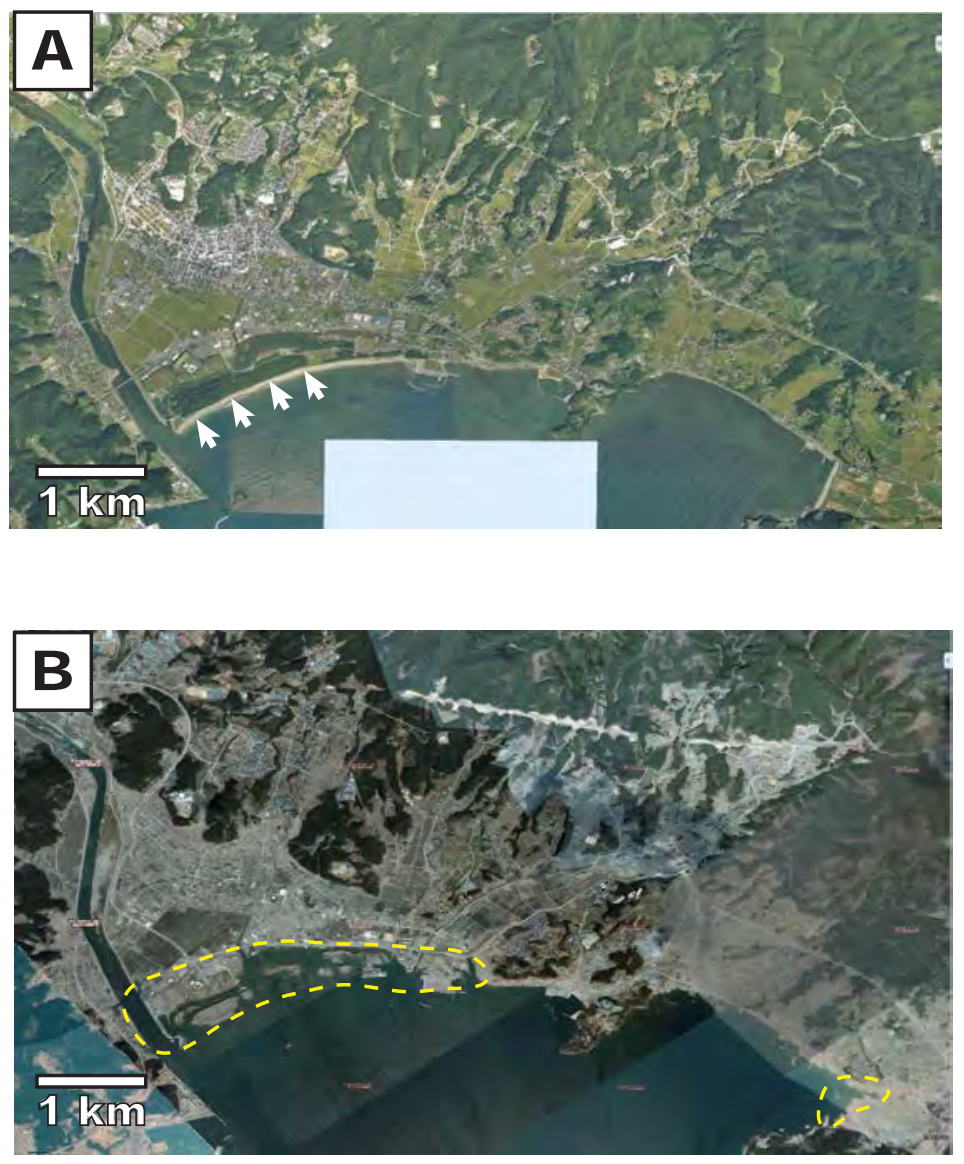

Naruse et al. Fig. 3 

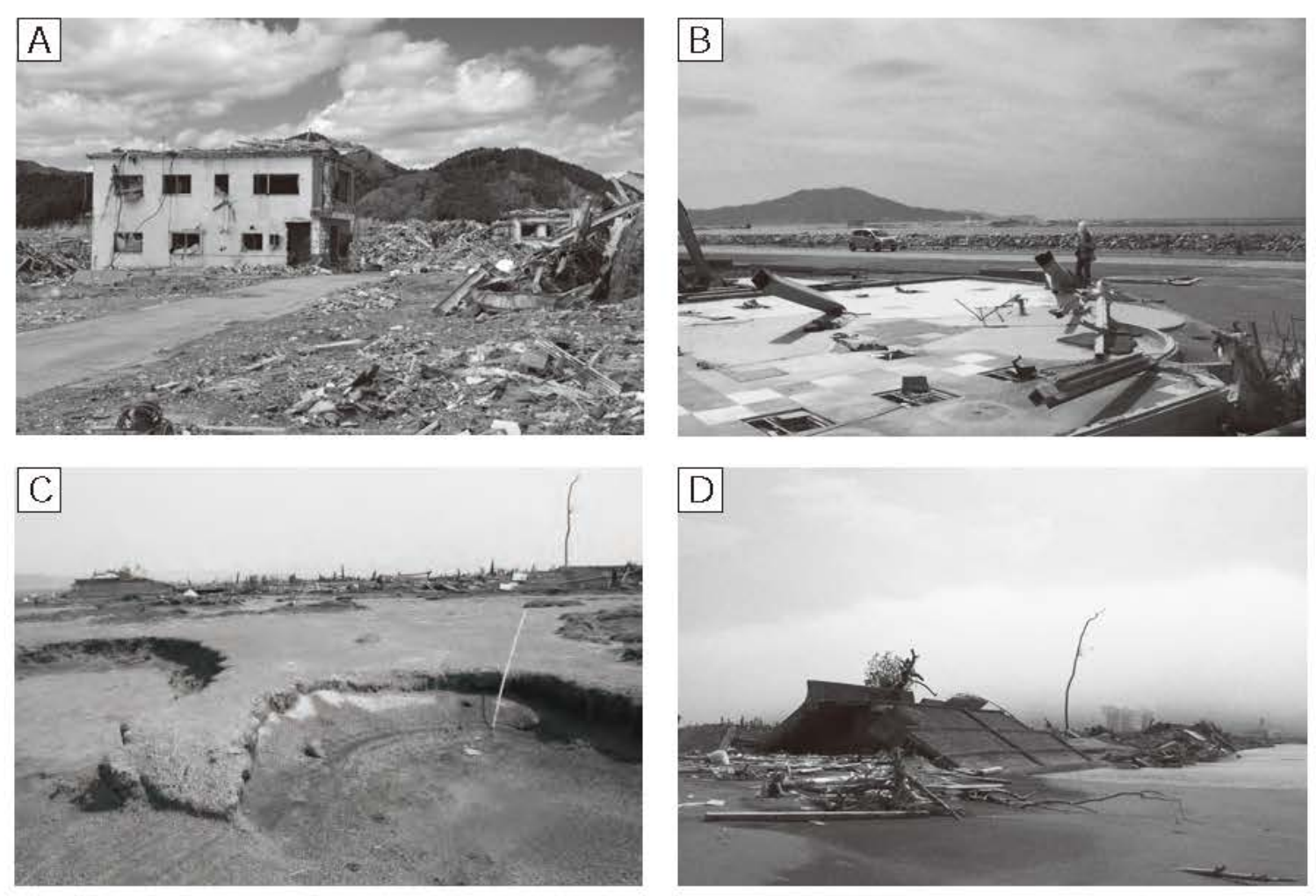

Naruse et al. Fig. 4 

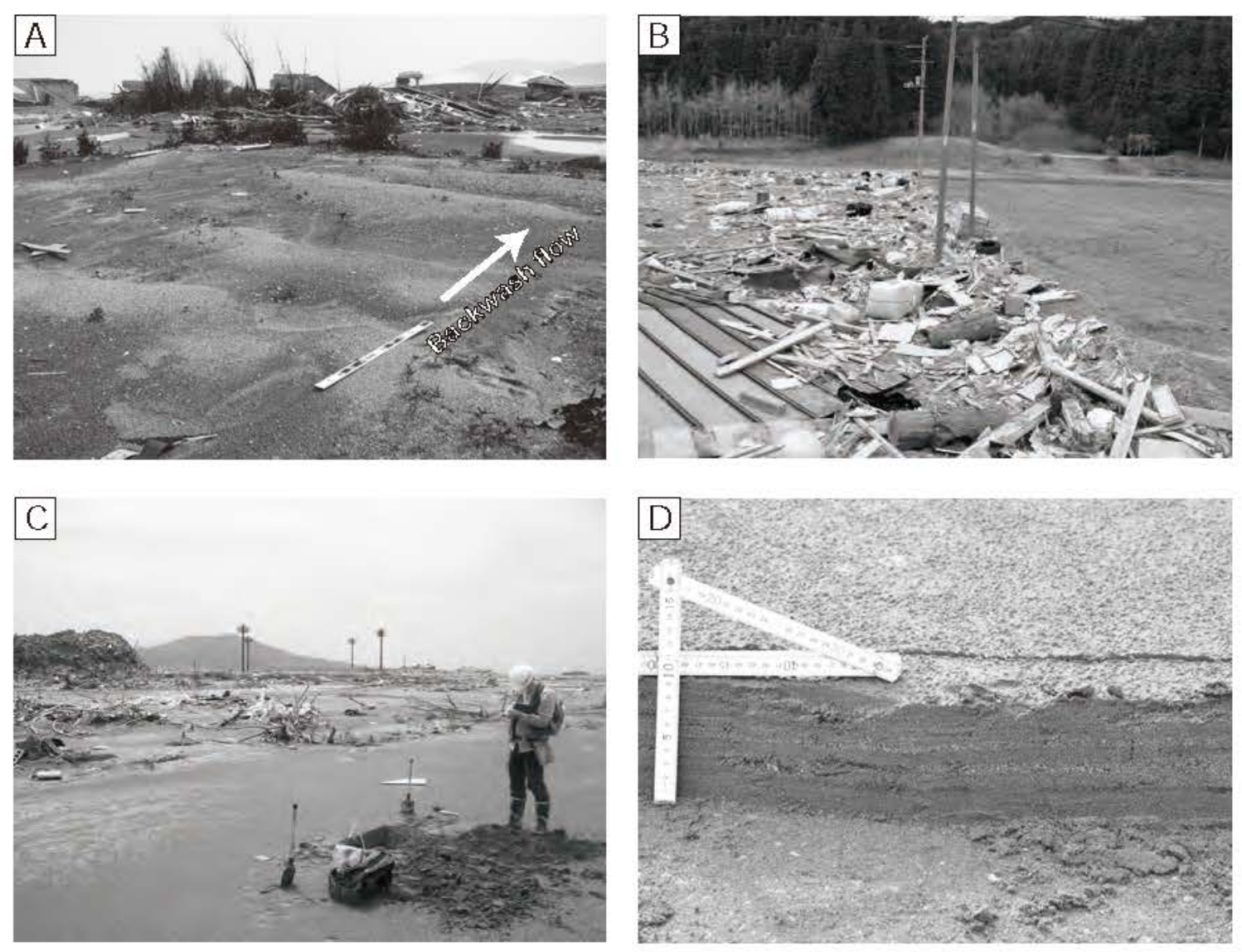

Naruse et al. Fig. 5 

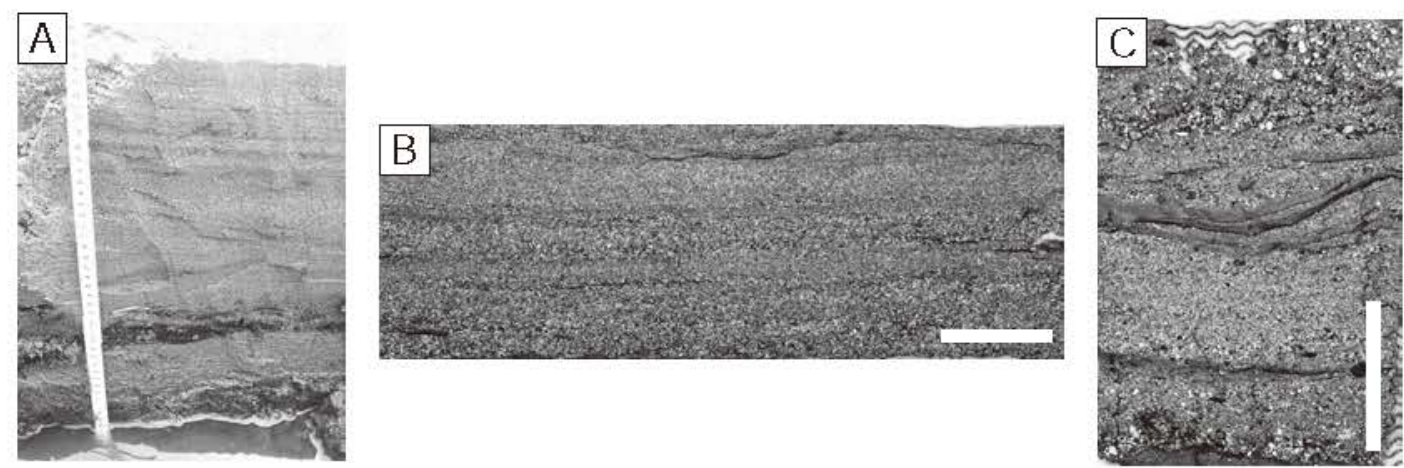

Naruse et al. Fig. 6 


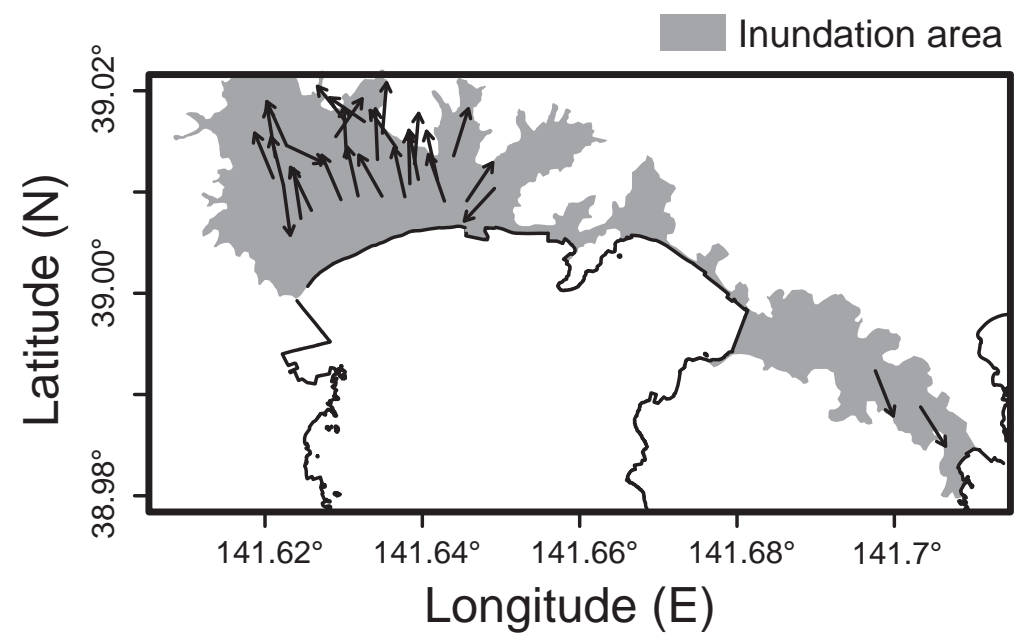

Naruse et al. Fig. 7 
Thickness of tsunami deposit at each sampling point

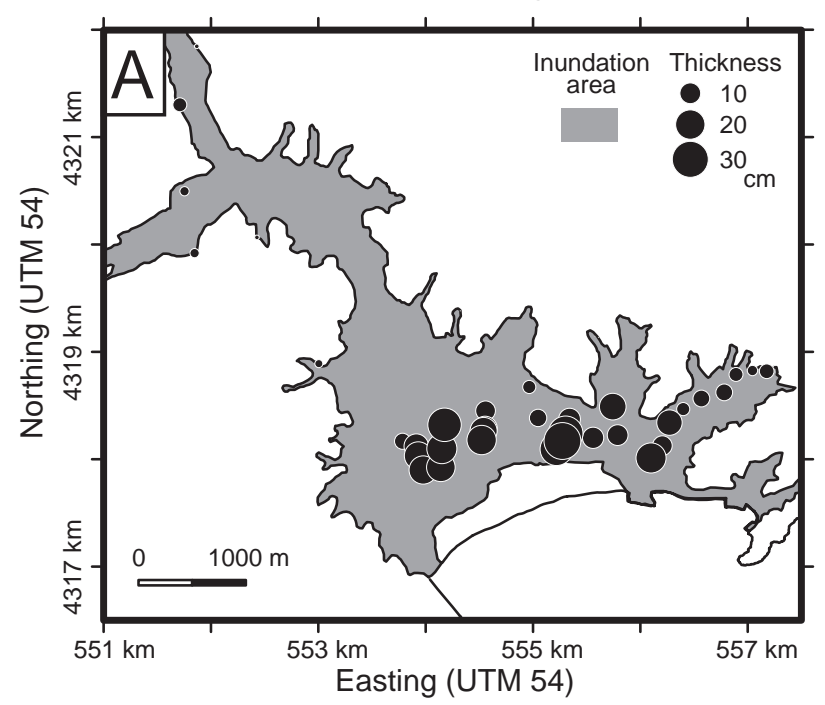

Estimated thickness distribution of tsunami deposit

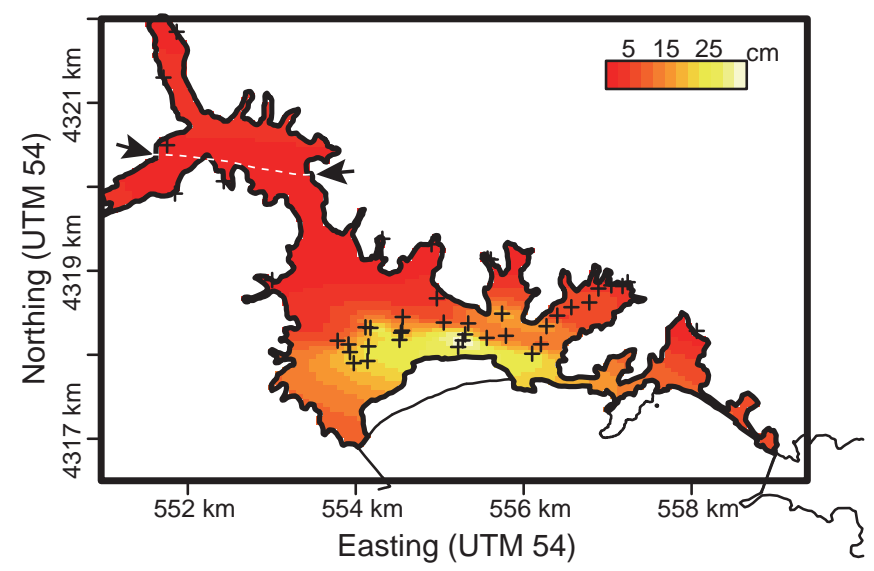

Standard error of thickness estimation

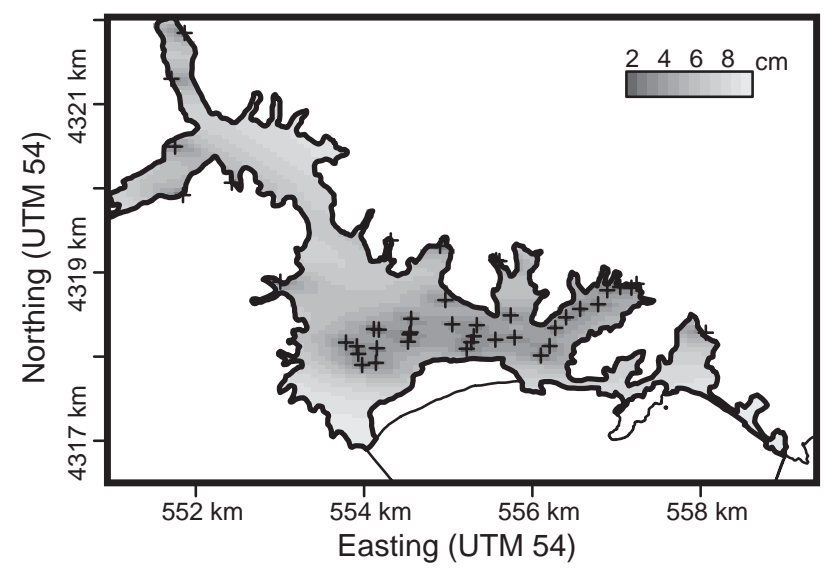

Naruse et al. Fig. 8 


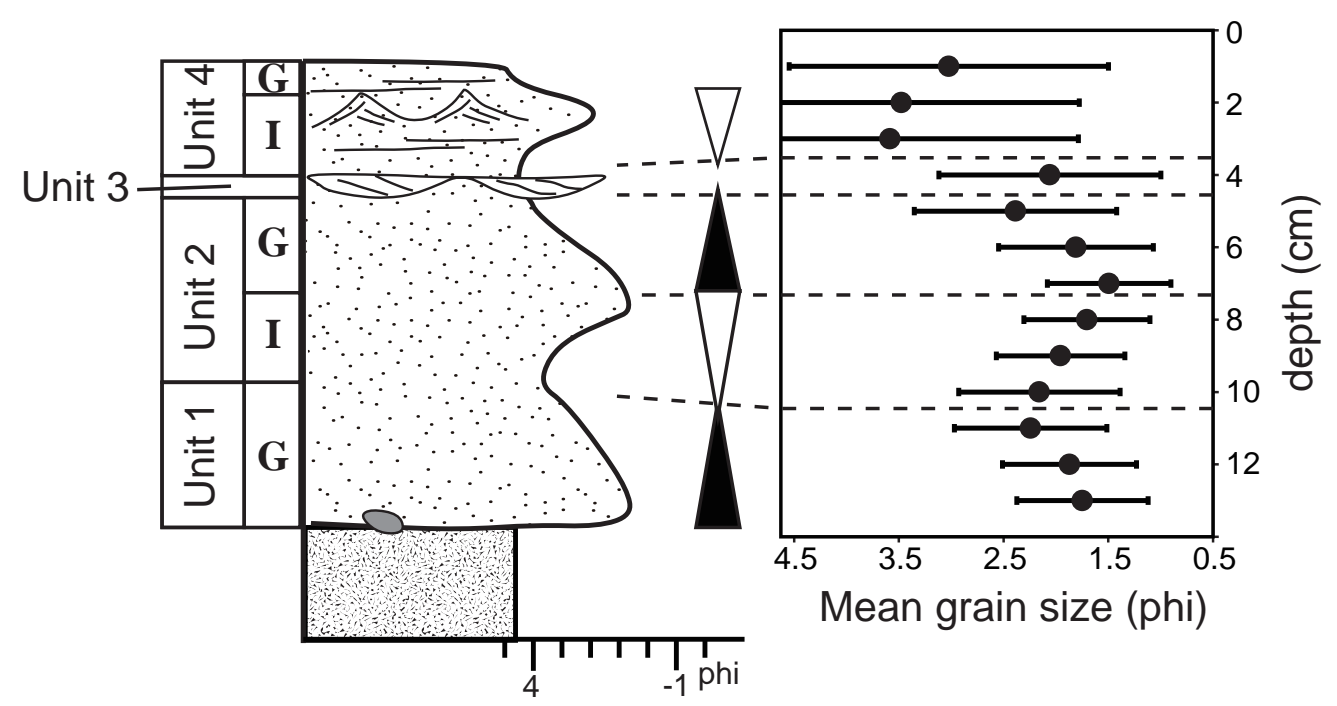

I: Inverse-graded sub-unit

G: Normal-graded sub-unit 

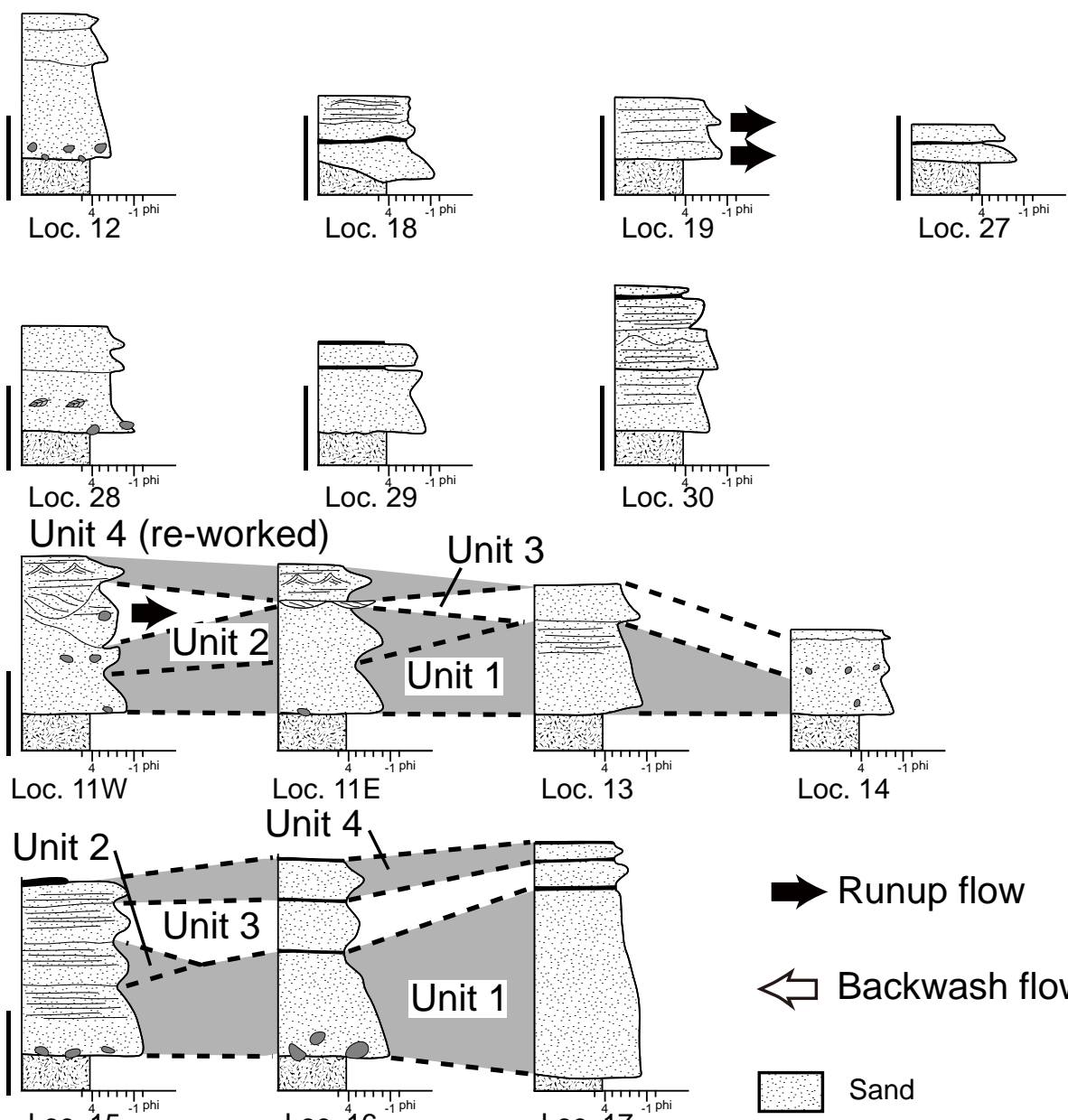

Unit 4 Unit 3

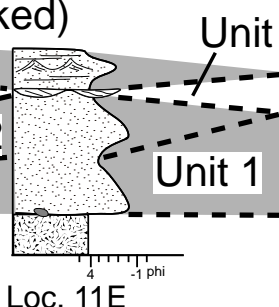

Unit 4
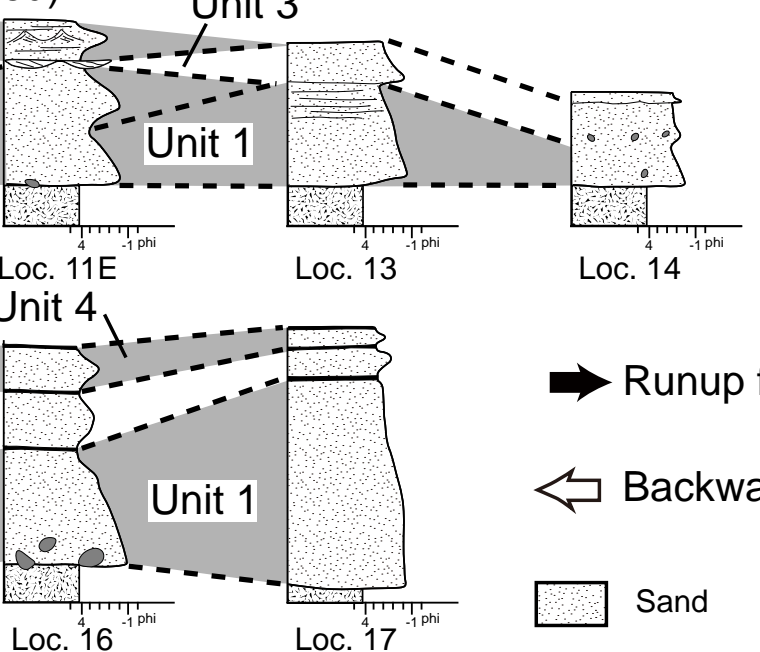

$\Rightarrow$ Runup flow

$\prec$ Backwash flow

$\square$ Sand

Unit 4 Unit 3

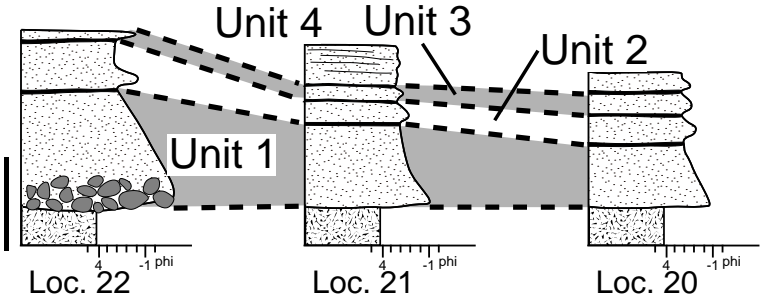

Soil

8808 Gravel

- Plant fragments

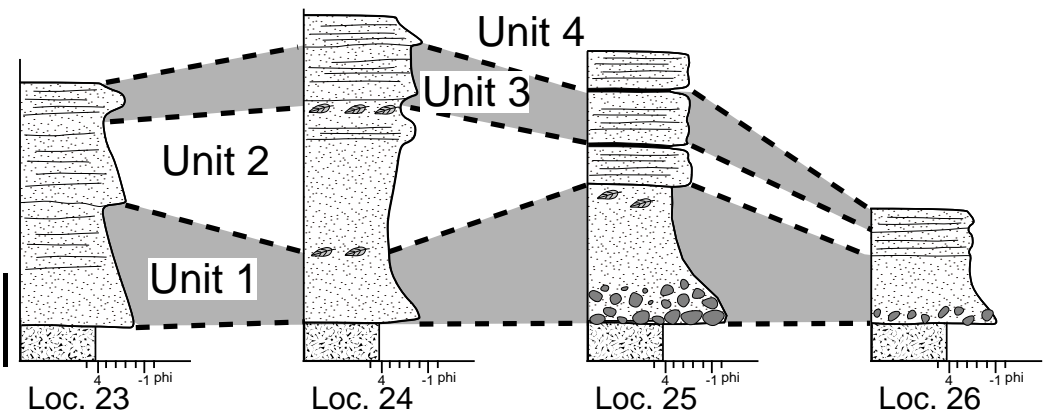




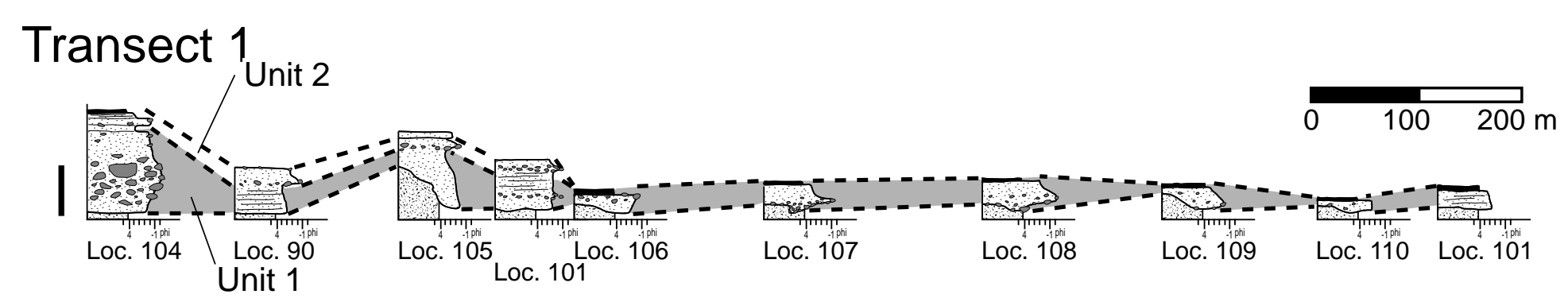

\section{Transect 2}

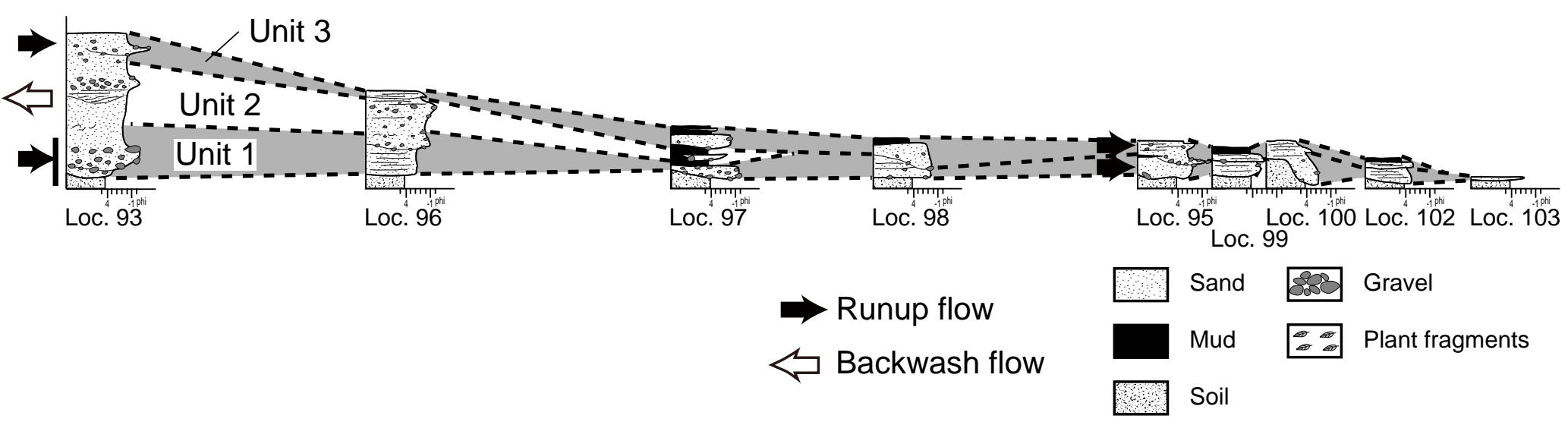



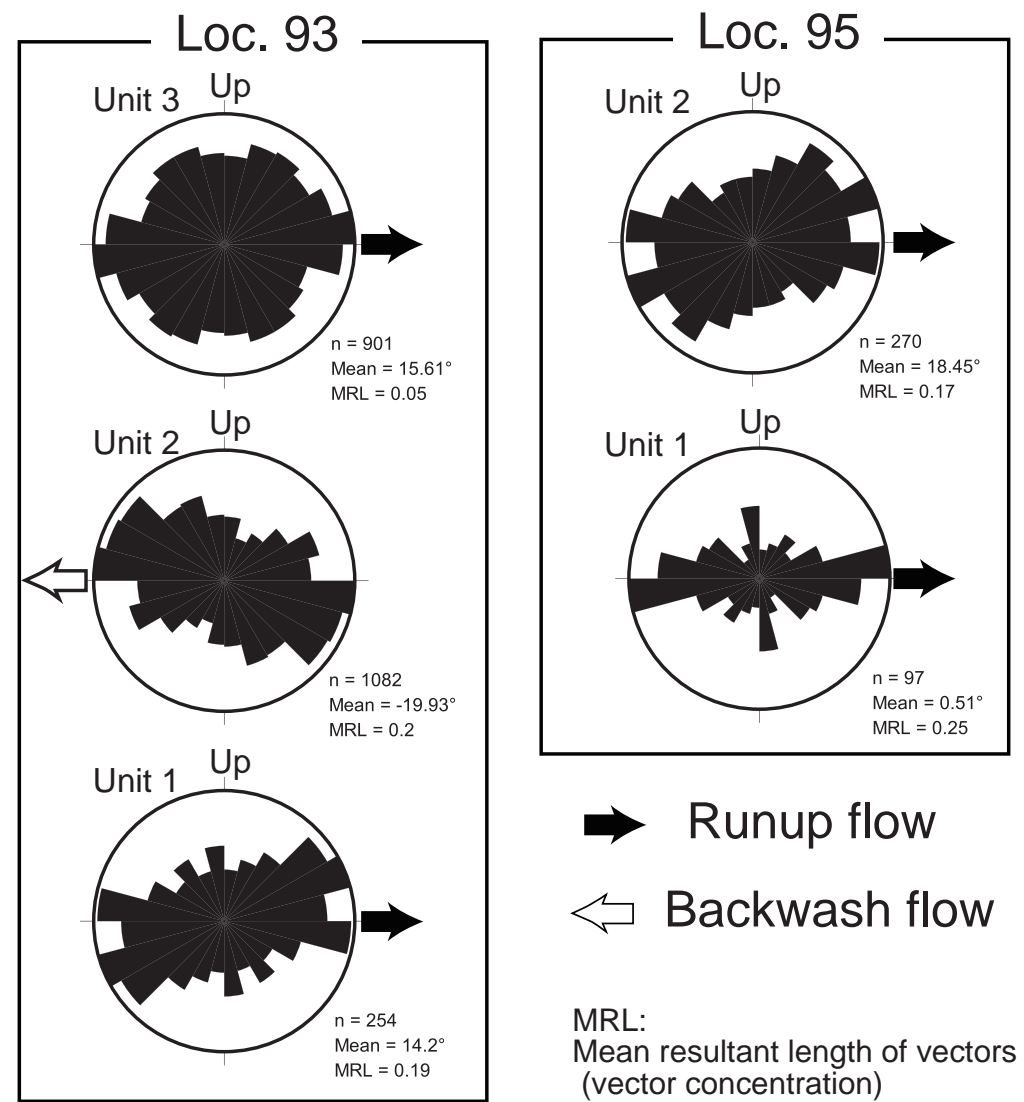

MRL:

Mean resultant length of vectors (vector concentration) 


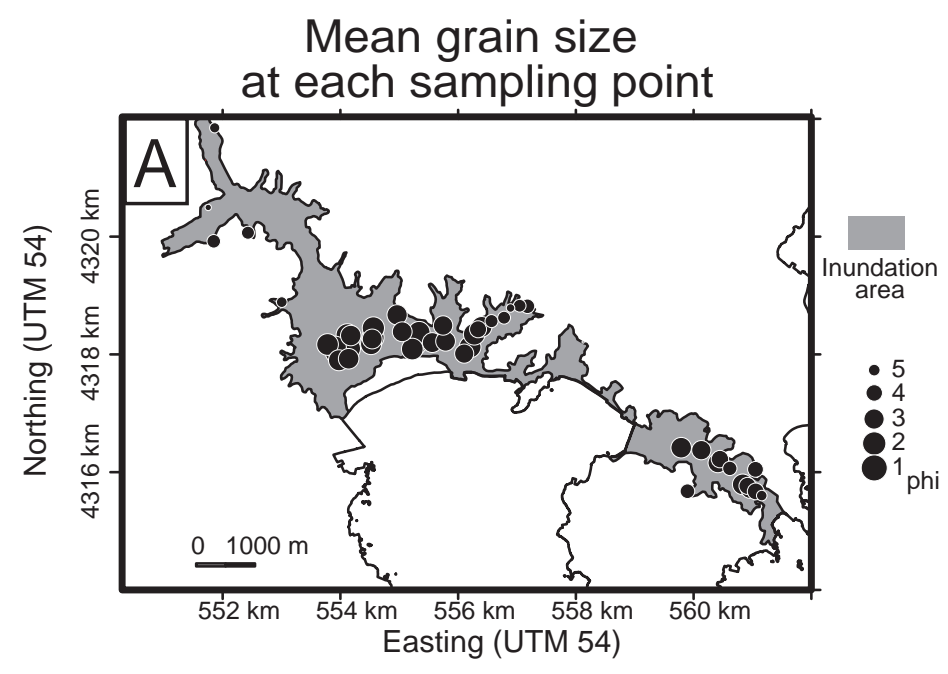

Estimated spatial distribution

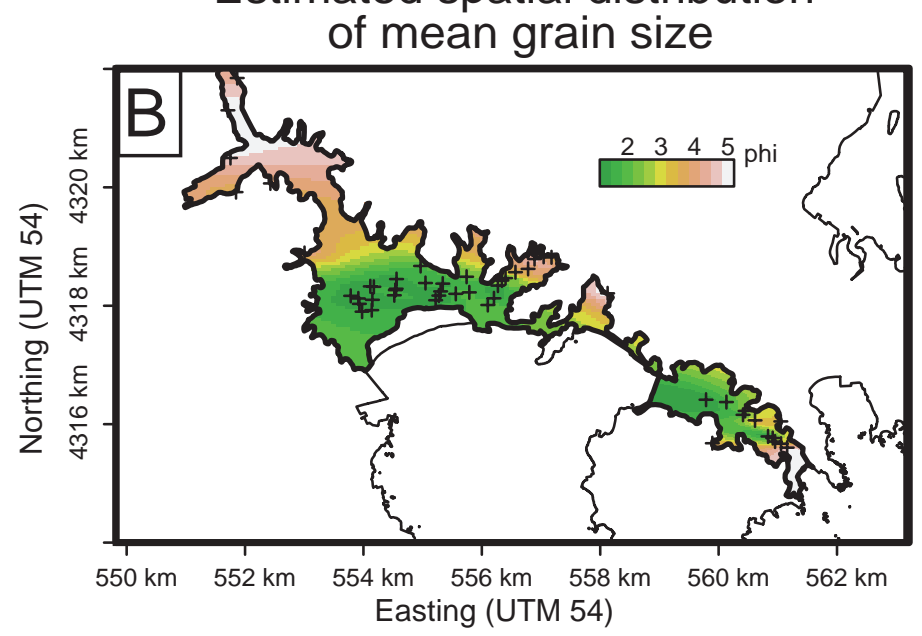

Standard error of estimation of mean grain size

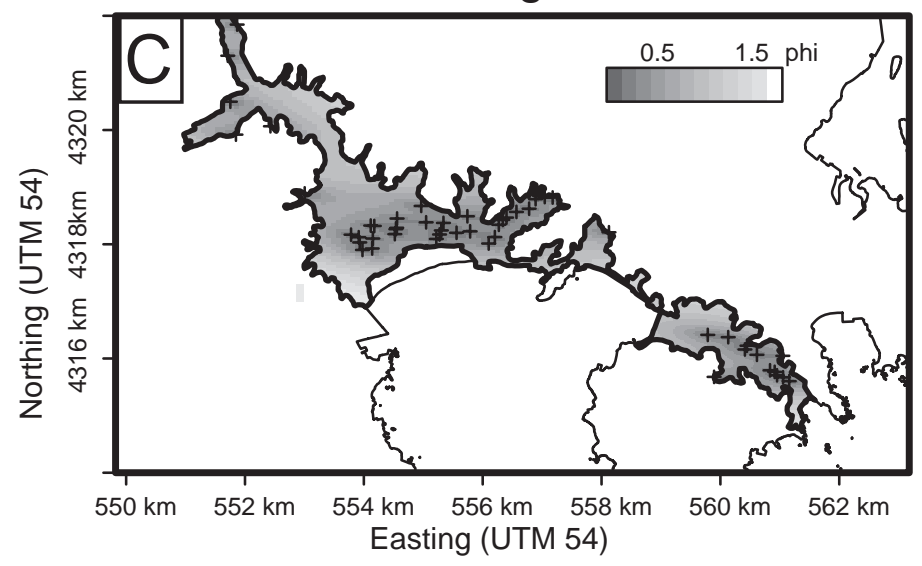




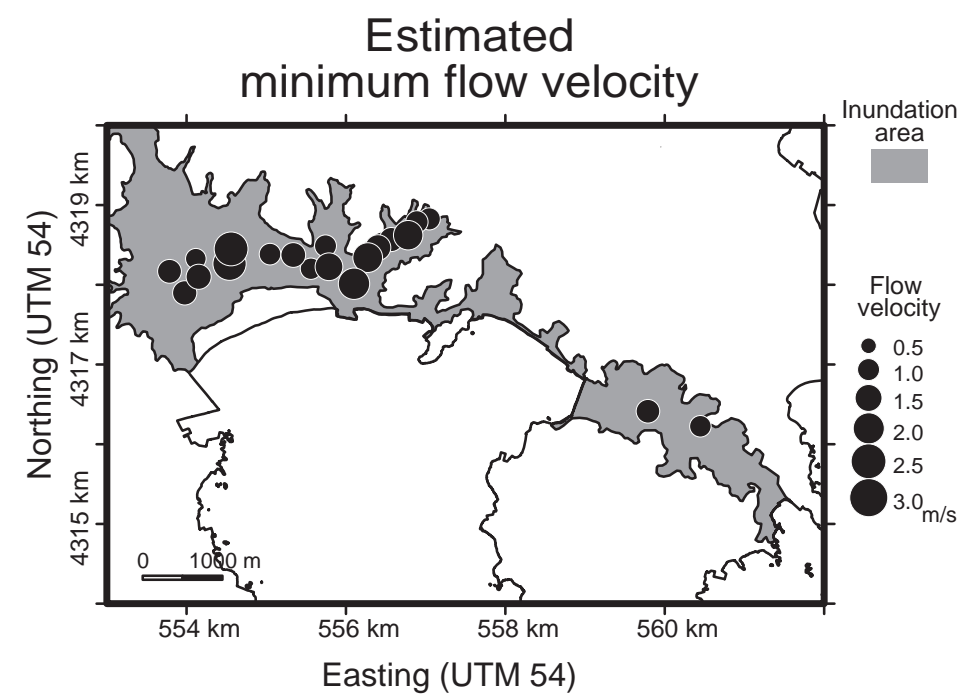

Naruse et al. Fig. 14 

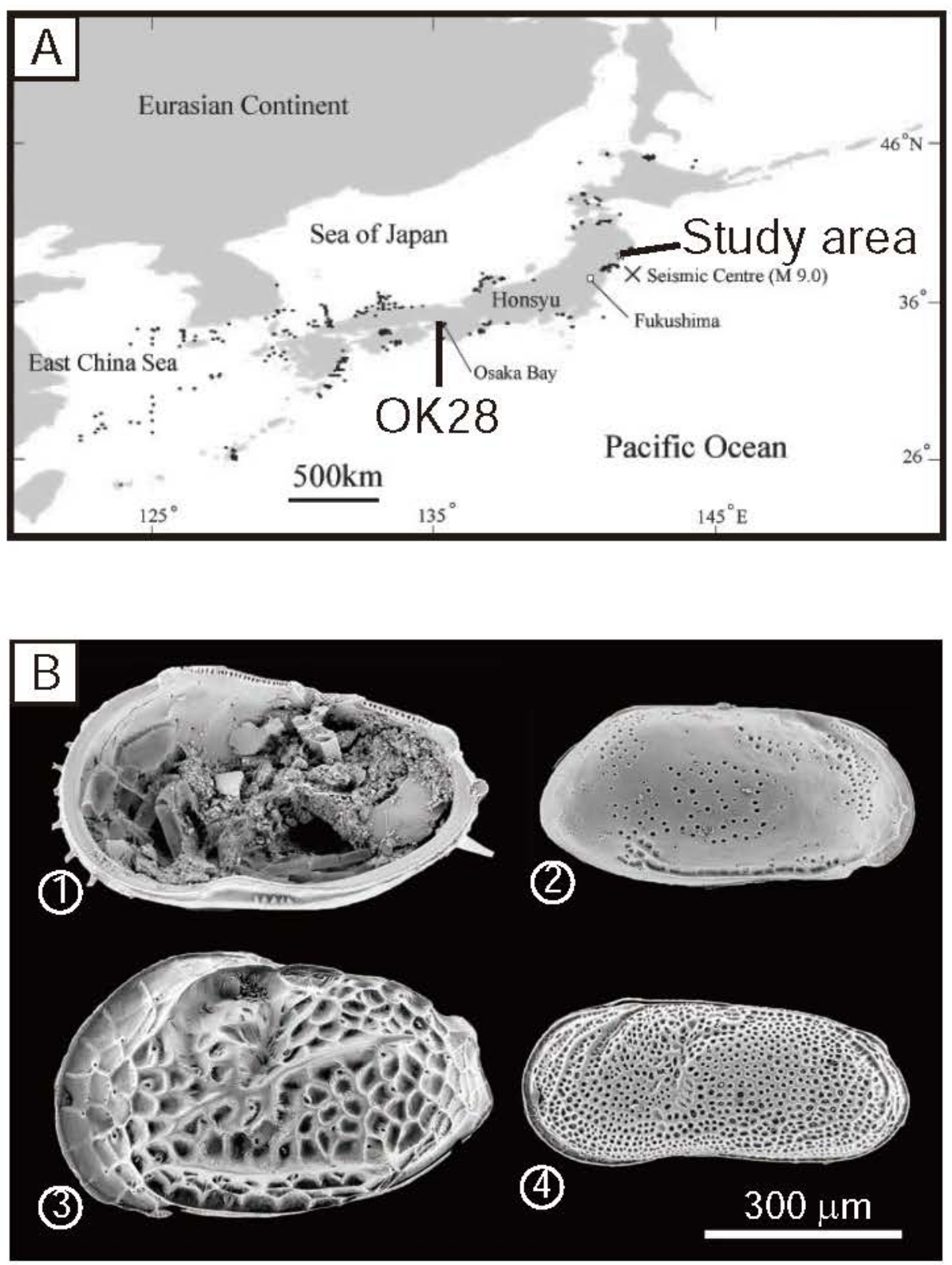

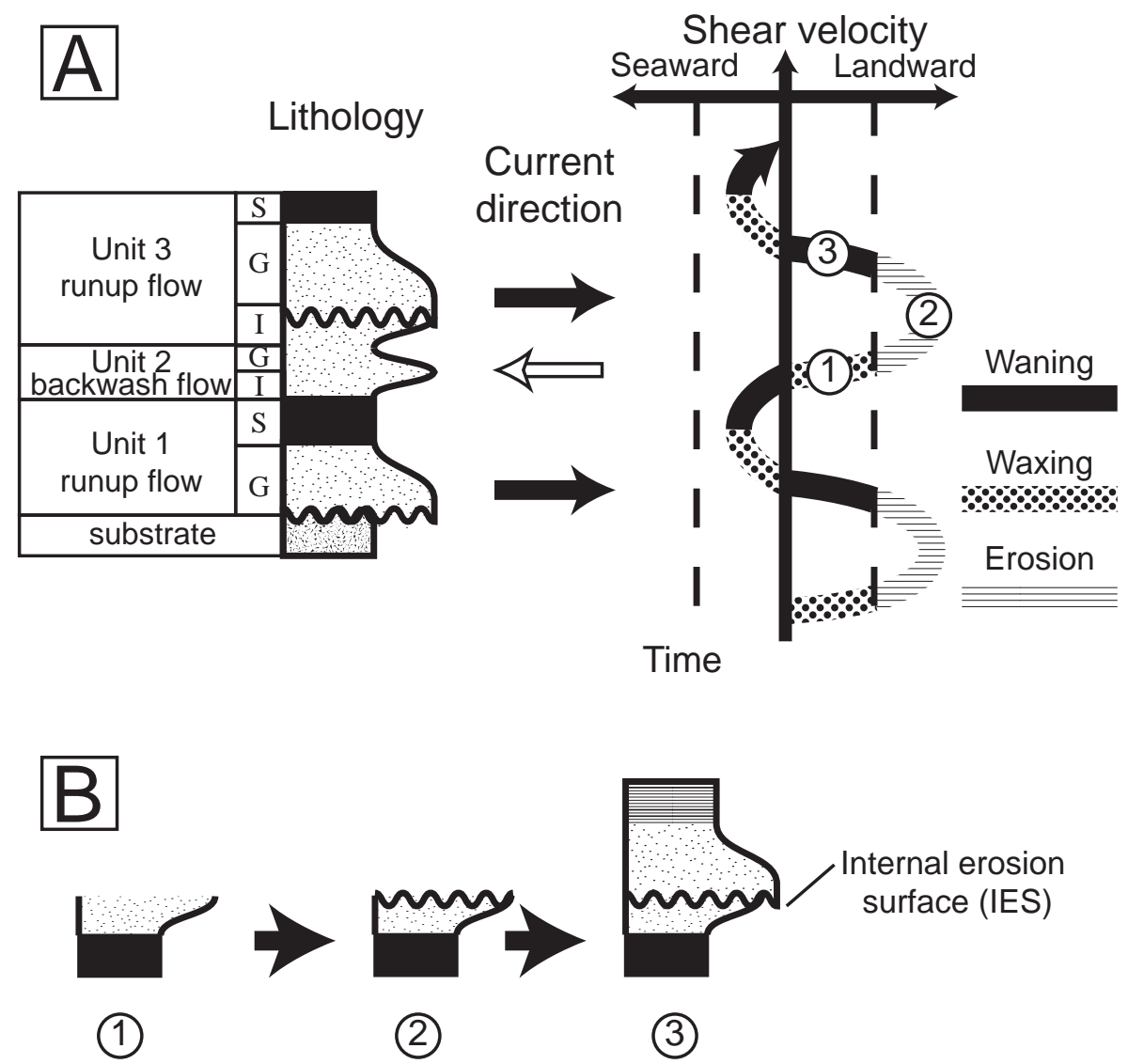

Naruse et al. Fig. 16 
Angulicytherura miii

Aurila corniculata

Bicornucythere bisanensis

Bythoceratina hanaii

Bythoceratina hanaii

Callistocythere japonica

Callistocythere undulatifacialis

Coquimba ishizakii

Cornucoquimba tosaensis

Cytherois nakanoumiensis

Cytheromorpha acupunctata Hemicytherura kajiyamai Howeina leptocytheroidea Kobayashiina donghaiensis Loxoconcha epeterseni

Loxoconcha japonica

Loxoconcha ozawai

Loxoconcha uranouchiensis

Neonesidea oligodentata

Nipponocythere bicarinata

Parakrithella pseudadonta

Pistocythereis bradyformis Pontocythere subjaponica Schizocythere kishinouyei

Semicytherura miurensis

Spinileberis quadriaculeata

Xestoleberis hanaii

Xestoleberis sagamiensis

Xestoleberis setouchiensis 


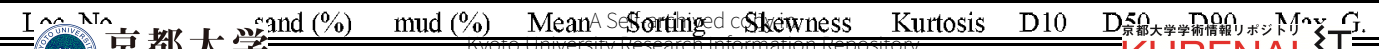

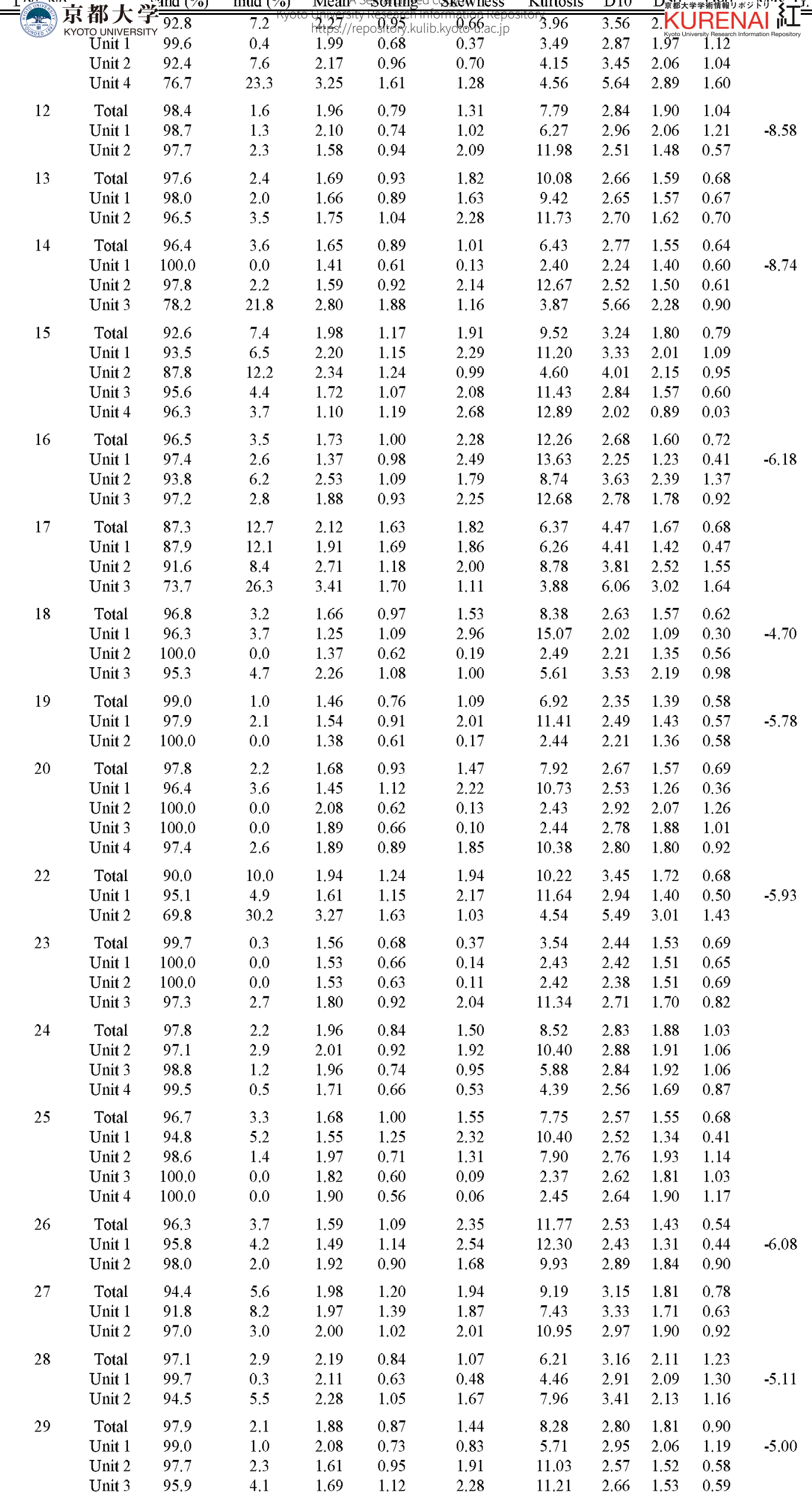

Naruse et al. Table 2 
京都大学 96.7

Unit $3 \quad 96.7$

32

36

37

40

41

43

54

56

59

66

90

95

96

97

98

99

102

Total 83.0

Unit $1 \quad 78.0$

Unit $2 \quad 56.7$

104

Total 86.3

Unit $1 \quad 91.6$

Unit $3 \quad 51.8$

105

Total 90.5

Unit $1 \quad 88.7$

Unit 295.5

Unit $3 \quad 90.8$

106

Total 78

Unit $1 \quad 86.6$

107

108

109

110

111

59.0

33.5

59.9
Unit $2 \quad 75.2$

Unit $2 \quad 54.0$

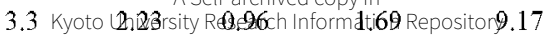

hitis/repogtgr.kulib.kyojogyac.jp

$3.3-2.03 \quad 0.98$

1.90

10.20

$\begin{array}{lll}64.7 & 4.78 & 1.80\end{array}$

0.02

$\begin{array}{llll}2.73 & 7.22 & 4.71 & 2.45\end{array}$

$\begin{array}{lll}40.7 & 3.93 & 1.91\end{array}$

0.59

0.89

0.35

$46.9 \quad 4.23 \quad 2.07$

$-0.03$

$-0.11$

0.85

18.3

2.76

1.67

$24.4 \quad 3.16 \quad 1.90$

1.06

0.72

$-0.25$

69.4

4.96

1.98

9.5

$2.02 \quad 1.47$

$\begin{array}{ll}1.88 & 1.49\end{array}$

1.64

1.56

2.19

10.2

$1.50 \quad 1.30$

15.5

2.08

1.48

1.61

1.56

1.31

8.3

$3.17 \quad 1.39$

6.3

1.89

1.50

1.64

1.58

1.72

1.81

0.58

1.80

1.29

1.71

1.38

0.86

1.27

0.71

0.60

0.81

$\begin{array}{lll}31.4 & 3.29 & 1.83\end{array}$

$\begin{array}{lll}21.4 & 2.77 & 1.74\end{array}$

$\begin{array}{lll}41.5 & 3.73 & 1.82\end{array}$

32.4

19.7

$\begin{array}{lll}34.9 & 3.61 & 1.82\end{array}$

$\begin{array}{lll}40.7 & 3.72 & 1.99\end{array}$

$\begin{array}{lll}17.0 & 2.67 & 1.58\end{array}$

220

43.3

$\begin{array}{ll}2.93 & 1.70 \\ 3.83 & 1.77\end{array}$

$\begin{array}{lll}13.7 & 2.52 & 1.55\end{array}$

$8.4 \quad 2.30 \quad 1.45$

$\begin{array}{lll}24.8 & 2.81 & 2.06\end{array}$

$\begin{array}{lll}48.2 & 4.13 & 1.86\end{array}$

$\begin{array}{lll}9.5 & 1.61 & 1.68\end{array}$

$\begin{array}{lll}11.3 & 1.52 & 1.78\end{array}$

$\begin{array}{lll}4.5 & 1.65 \quad 1.40\end{array}$

$\begin{array}{lll}9.2 & 2.00 & 1.60\end{array}$

$\begin{array}{lll}21.5 & 2.43 & 1.91\end{array}$

$\begin{array}{lll}13.4 & 1.86 & 1.89\end{array}$

$\begin{array}{lll}46.0 & 4.13 & 1.99\end{array}$

$\begin{array}{lll}41.0 & 3.74 & 1.99\end{array}$

$\begin{array}{lll}44.2 & 3.78 & 2.41\end{array}$

$\begin{array}{lll}66.5 & 4.87 & 1.89\end{array}$

$40.1 \quad 3.80 \quad 1.94$

$\begin{array}{lll}6.9 & 2.41 & 1.19\end{array}$

$\begin{array}{lll}3.0 & 2.23 & 1.00\end{array}$

$\begin{array}{cc}\text { Total } & 93.1 \\ \text { Unit } 1 & 97.0\end{array}$

Unit 2

Unit 3

$\begin{array}{lll}11.5 & 2.54 & 1.40\end{array}$

$\begin{array}{lllll}0.81 & 3.21 & 5.98 & 2.90 & 1.25 \\ 1.07 & 3.73 & 5.37 & 2.32 & 0.94\end{array}$

$\begin{array}{lllll}0.49 & 2.59 & 6.28 & 3.53 & 1.50\end{array}$

$\begin{array}{lllll}0.79 & 3.17 & 6.12 & 2.95 & 1.30\end{array}$

$\begin{array}{lllll}1.19 & 4.07 & 5.29 & 2.27 & 0.98\end{array}$

$\begin{array}{lllll}0.75 & 2.90 & 6.33 & 3.21 & 1.56\end{array}$

$\begin{array}{lllll}0.52 & 2.62 & 6.63 & 3.33 & 1.40\end{array}$

$\begin{array}{lllll}1.30 & 5.55 & 4.48 & 2.44 & 0.96\end{array}$

$\begin{array}{lllll}1.00 & 3.76 & 5.41 & 2.58 & 1.08\end{array}$

$\begin{array}{lllll}0.42 & 2.78 & 6.29 & 3.67 & 1.61\end{array}$

$\begin{array}{lllll}1.42 & 6.08 & 4.18 & 2.30 & 0.88\end{array}$

$\begin{array}{lllll}1.61 & 6.85 & 3.66 & 2.11 & 0.80\end{array}$

$\begin{array}{lllll}0.83 & 3.02 & 6.01 & 2.34 & 0.54\end{array}$

$\begin{array}{lllll}0.42 & 2.56 & 6.73 & 3.93 & 1.83\end{array}$

$\begin{array}{lllll}1.65 & 6.03 & 3.99 & 1.20 & 0.03\end{array}$

$\begin{array}{lllll}1.77 & 5.89 & 4.30 & 1.02 & -0.04\end{array}$

$\begin{array}{lllll}1.48 & 6.78 & 3.15 & 1.46 & 0.14\end{array}$

$\begin{array}{lllll}1.29 & 5.32 & 3.84 & 1.78 & 0.25\end{array}$

$\begin{array}{lllll}1.27 & 4.34 & 5.39 & 1.91 & 0.54\end{array}$

$\begin{array}{lllll}1.56 & 5.01 & 4.84 & 1.28 & 0.15\end{array}$

$\begin{array}{lllll}0.42 & 2.36 & 7.05 & 3.78 & 1.71\end{array}$

0.51

2.39

$\begin{array}{llllll}0.30 & 1.88 & 7.18 & 3.40 & 0.84 & -7.54\end{array}$

$-0.09$

$\begin{array}{llll}2.36 & 7.33 & 4.95 & 2.24\end{array}$

0.60

2.55

$\begin{array}{lll}6.69 & 3.41 & 1.54\end{array}$

$\begin{array}{lllll}1.59 & 7.93 & 3.63 & 2.27 & 1.15\end{array}$

$\begin{array}{llllll}1.57 & 8.86 & 3.25 & 2.15 & 1.12 & -7.01\end{array}$

$\begin{array}{lllll}1.77 & 7.96 & 3.83 & 2.42 & 1.29\end{array}$

$\begin{array}{llll}6.36 & 4.06 & 2.34 & 1.07\end{array}$

$\begin{array}{llll}6.61 & 3.37 & 1.39 & \mathbf{- 5 . 9 5}\end{array}$

$-5.48$

$-5.32$

Naruse et al. Table 2 (contd.) 